\title{
HYDROLOGIC EVALUATION OF PART OF CENTRAL VOLUSIA COUNTY, FLORIDA
}

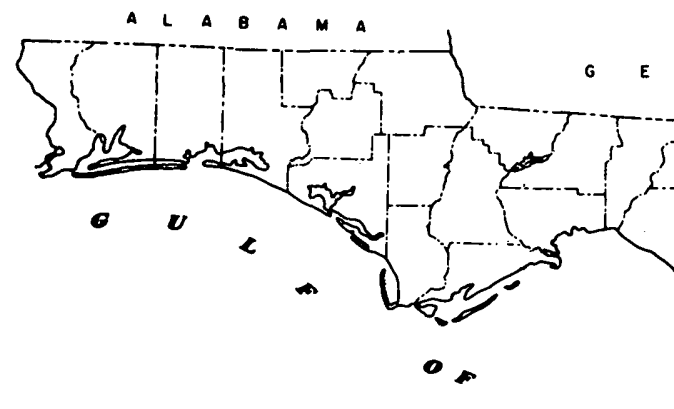

\section{U.S. GEOLOGICAL SURVEY}

Water-Resources Investigations 78-89

Prepared in cooperation with

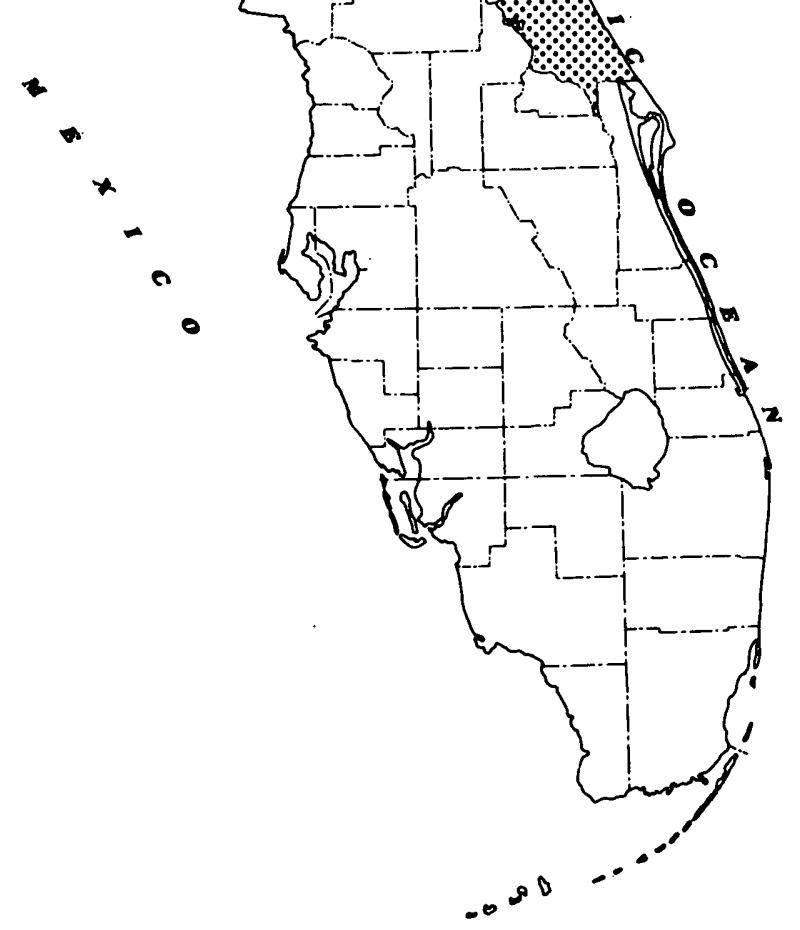
VOLUSIA COUNTY, FLORIDA 

HYDROLOGIC EVALUATION OF PART OF CENTRAL VOLUSIA COUNTY, FLORIDA

By Peter W. Bush

U.S. GEOLOGICAL SURVEY

Water-Resources Investigations

Prepared in cooperation with

VOLUSIA COUNTY, FLORIDA

Tallahassee, Florida

1978

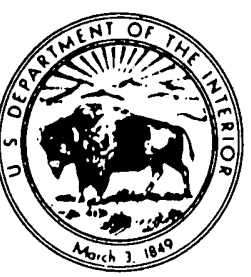




\section{UNITED STATES DEPARTMENT OF THE INTERIOR \\ CECIL D. ANDRUS, Secretary \\ GEOLOGICAL SURVEY \\ H. William Menard, Director}

\section{Open-File Report}

For additional information write to:

U.S. Geological Survey

325 John Knox Road

Building F, Suite 240

Tallahassee, Florida 32303 
$\vdots$ 
CONTENTS

Page

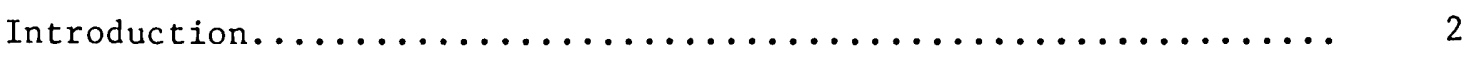

Conceptual model of the hydrologic system............... 5

Suitability and application of the digital model........... 9

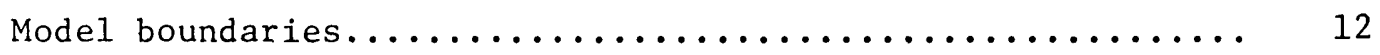

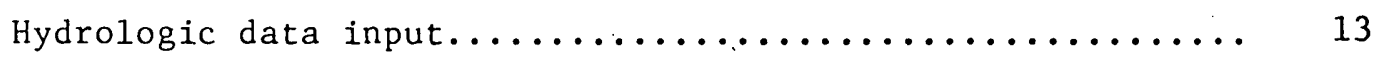

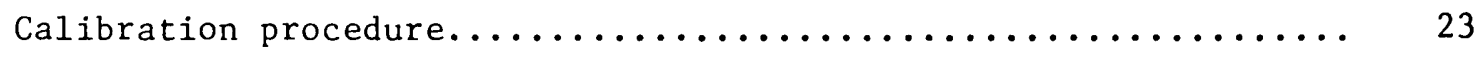

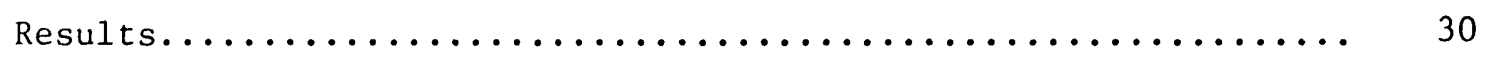

Conclusions...................................... 44

References................................. 50

\section{ILLUSTRATIONS}

Figure

Page

1. Map showing location of physiographic features, central wetlands area, and proposed well field.............. 3

2. Block diagram of part of Volusia County providing generalized view of the hydrologic system.............

3-17. Maps showing:

3. Final grid superimposed on model area............. 11

4. Unstressed potentiometric surface of the Floridan aquifer representing average conditions.................

5. Estimated altitude of the potentiometric surface of the

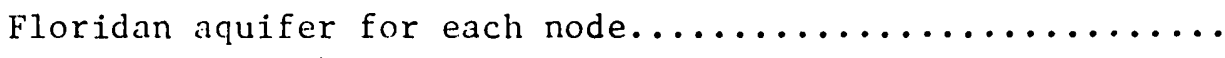




\section{ILLUSTRATIONS (continued)}

Figure

Page

6. Estimated altitude of the potentiometric surface of the

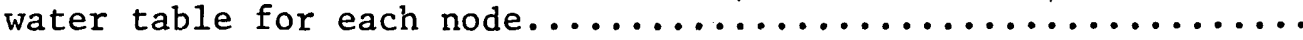

7. Estimated transmissivity of the Floridan aquifer for each

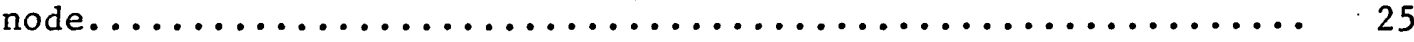

8. Estimated recharge for each node................... 26

9. Steady-state cone of depression due to simulated pumping of 20 million gallons per day; leakage limited to a maximum of

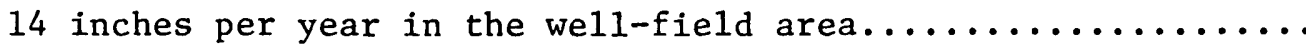

10. Steady-stage drawdown values for each node near the center of pumping due to simulated withdrawal of 20 million gallons per day from 67 wells; leakage limited to a maximum of 14

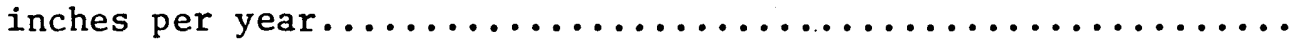

11. Potentiometric surface resulting from cone of depression from figure 9 (20 million gallons per day, maximum allowable leakage 14 inches per year) superimposed on unstressed potentiometric

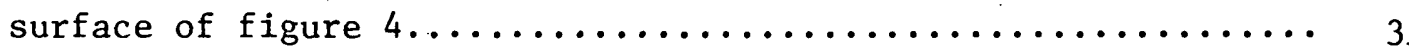

12. Steady-state drawdown values for each node near the center of pumping due to withdrawal of 20 million gallons per day from 8 wells; leakage 1imited to a maximum of 14 inches per

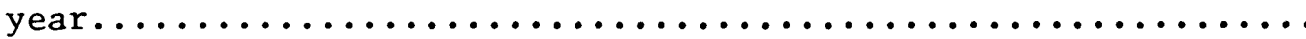

13. Steady-state drawdown values for each node near the center of pumping due to withdrawal of 20 million gallons per day from 18 wells; leakage limited to a maximum of 14 inches per year 


\section{ILLUSTRATIONS (continued)}

Figure

Page

14. Steady-state cone of depression due to simulated pumping of 20 million gallons per day; leakage limited to a maximum of 5 inches per year in the well-field area.......

15. Potentiometric surface resulting from cone of depression from figure 14 (maximum allowable leakage 5 inches per year) superimposed on unstressed potentiometric surface of

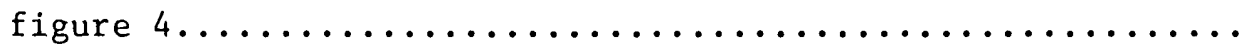

16. Steady-state cone of depression due to simulated pumping of 20 million gallons per day; leakage limited to 5 inches per year in every other node in the well-field area, leakage unrestricted in all other nodes.............. 45

17. Potentiometric surface resulting from cone of depression from figure 16 (20 million gallons per day, maximum allowable leakage 5 inches per year in every other node, unrestricted in all other nodes) superimposed on unstressed potentiometric surface of figure $4 \ldots \ldots \ldots \ldots \ldots \ldots \ldots \ldots$

TABLE

Table

1. Mass balance for unstressed conditions................ 

HYDROLOGIC EVALUATION OF PART OF CENTRAL VOLUSIA COUNTY, FLORIDA

\author{
By \\ Peter W. Bush \\ ABSTRACT
}

Municipal wells close to the Atlantic Coast cannot be expected to supply the steadily increasing population of Volusia County indefinitely without causing saltwater intrusion problems. Therefore, new wells will be drilled away from the coast. The source of water for the planned artesian aquifer well field will be leakage from the water-table aquifer above. A digital model of the leaky aquifer system indicates that long-term yield of about 20 million gallons per day can be expected without the cone of depression dropping low enough to cause saltwater intrusion. Some types of land development could remove potential recharge from the area. Model tests with decreased leakage indicate that a large amount of potential recharge water would have to be removed from the system to effect an appreciable lowering of the cone of depression. Lowering the recharge potential by 20 percent apparently would have little effect on the cone. Lowering the recharge potential by 60 percent would, according to the model, increase the maximum depth of the cone by 27 percent. Land development that would redistribute potential recharge, rather than drain it away from the system, would have little effect on the aquifer beneath the we11 field. 


\section{INTRODUCTION}

Volusia County officials are aware that well fields relatively close to the coast cannot be expected to supply a steadily increasing population indefinitely without saltwater intrusion problems. Present demand for water in the county, about 30 million gallons per day, is expected to nearly triple to 85 million gallons per day by 1990 (Volusia Council of Governments, 1974, p. i).

The Floridan aquifer is the principal aquifer for water supplies in central Florida. Previous water resources studies in Volusia County documented a dome in the potentiometric surface of the Floridan aquifer in the central part of the county (U.S. Army Corps of Engineers, 1933; Wyrick, 1960, fig. 13; Knochenmus and Beard, 1971, fig. 15). This dome is generally coincident with the potentiometric surface of the clastic, or water-table aquifer overlying the Floridan aquifer; both potentiometric surfaces are close to land surface. In its natural condition, this flat terrace area in the central part of the county (fig. 1) is wet and swampy and allows little natural recharge since both the water-table and Floridan aquifers are full.

Recognizing the potential of this area as a source of future water supply; the U.S. Geological Survey and Volusia County initiated a cooperative investigation in 1973 of the potential of this area for water supply. The first phase of the project was a core-drilling program to determine the leakage, or recharge potential of the central wetlands area. In other words, if a gradient is created between the water-table and Floridan aquifers by pumping from the Floridan aquifer, is the 


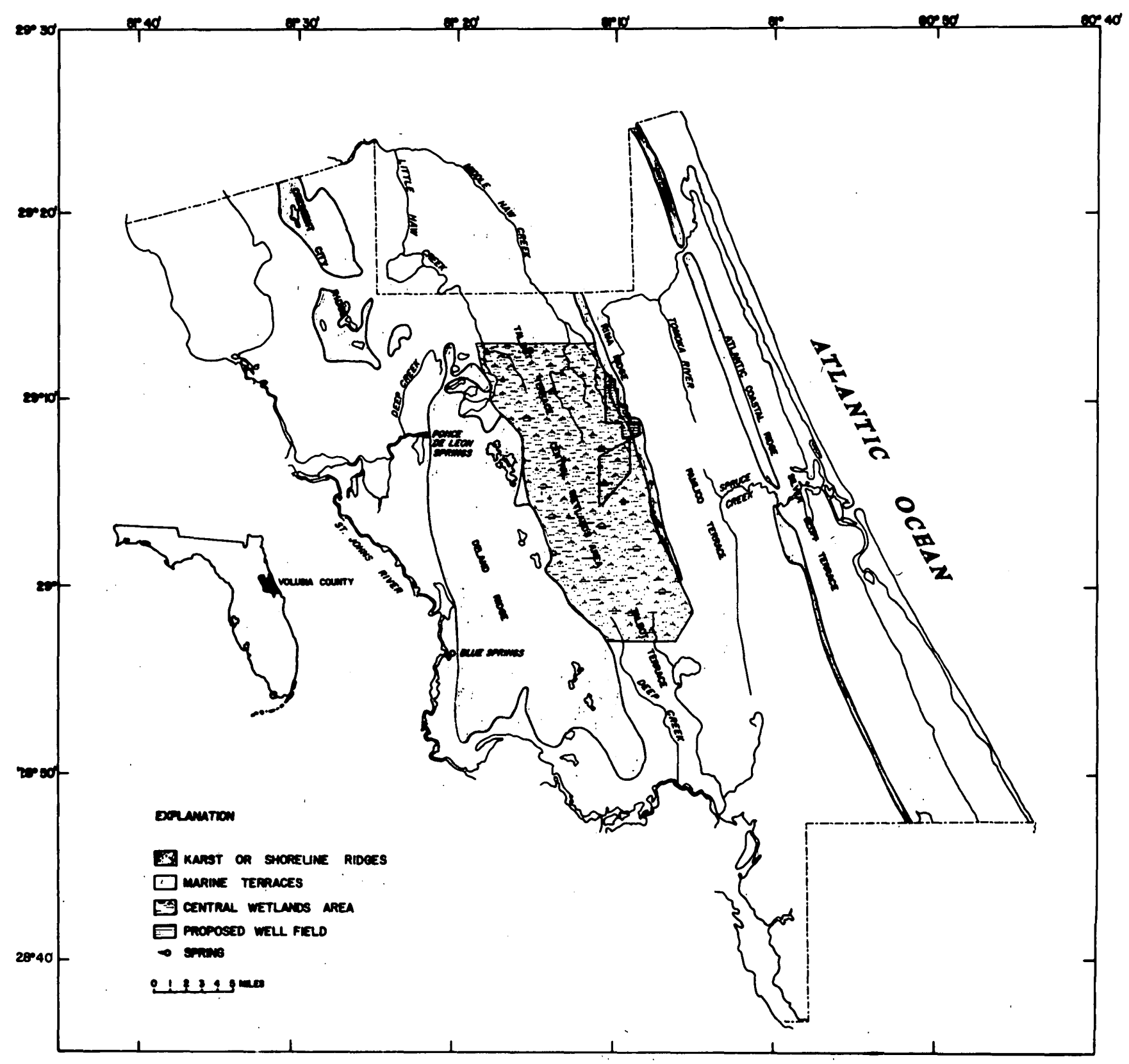

F.1gure 1.--Physiographic features, central wetlands area, and proposed well field. 
confining bed between those aquifers permeable enough to allow water to flow downward and replenish the Floridan aquifer? The conclusion from the drilling effort was that good potential for downward leakage exists in the area, and wells withdrawing water from the Floridan aquifer could be sustained by leakage from the water-table aquifer ( $\mathrm{J}$. 0. Kimrey, oral commun. 1974).

With this information, the county submitted application to the Florida Department of Natural Resources for funds to purchase selected parts of this potential recharge area under the Land Conservation Act of 1972, designed to protect environmentally endangered lands. Subsequently, tracts of land were purchased by the state and by the county for well-field development (fig. 1). The first objective of this report is to determine how much water could be withdrawn over the long term from a well field within the bounds of the property without allowing the cone of depression to drop low enough to cause saltwater intrusion. Increased development in the potential recharge area is expected as the population grows, and as land costs rise in coastal and west Volusia areas. Some types of development could reduce the amount of recharge to replenish the well field, or change the pattern of recharge distribution. The second objective is to determine the effects on the cone of depression of an operating well field due to a reduction in recharge, or a change in recharge distribution. This information would help guide the county in enacting controls on land use and density of development in the potential recharge area. 
This report presents the results of the study of potential yield and sensitivity to changes in recharge using the Pinder-Trescott digital computer model for aquifer evaluation (Pinder, 1970; Trescott, 1973).

CONCEPTUAL MODEL OF THE HYDROLOGIC SYSTEM

A conceptual model of Volusia County's hydrologic system, as interpreted by Knochenmus and Beard (1971, fig. 5), is shown in figure 2. Landforms (fig. 1) are a series of coast-parallel karst ridges, marine terraces, and shoreline ridges. The ridges are sandy, and well drained compared to the flat swampy terraces.

As stated in the introduction and shown in figure 2, a two-aquifer system exists in Volusia County. The upper one, the water-table aquifer, is made up of discontinuous, lenticular, interfingering beds of poorly consolidated sand, clayey sand, and shell. The water-table aquifer is 60 to 100 feet thick in the central wetlands area. Fine to medium sand occurs near land surface, usually grading into clayey sand, then intermixed beds of clay, shell, and sandy clay with depth. Mar1 is often the lowermost material of the water-table aquifer. The clay, sandy clay, and marl generally occurring in the lower half of the water-table aquifer is considered a confining or impeding layer to the exchange of water with the lower aquifer.

The Floridan aquifer, beneath the water-table aquifer, is a thick sequence of limestone and dolomite. The Floridan aquifer in Volusia County is characterized by alternative beds of porous, honeycomblike dolomitic limestone and beds of hard, dense dolomitic limestone. The hard, dense layers are relatively low in hydraulic conductivity, and thus tend to 


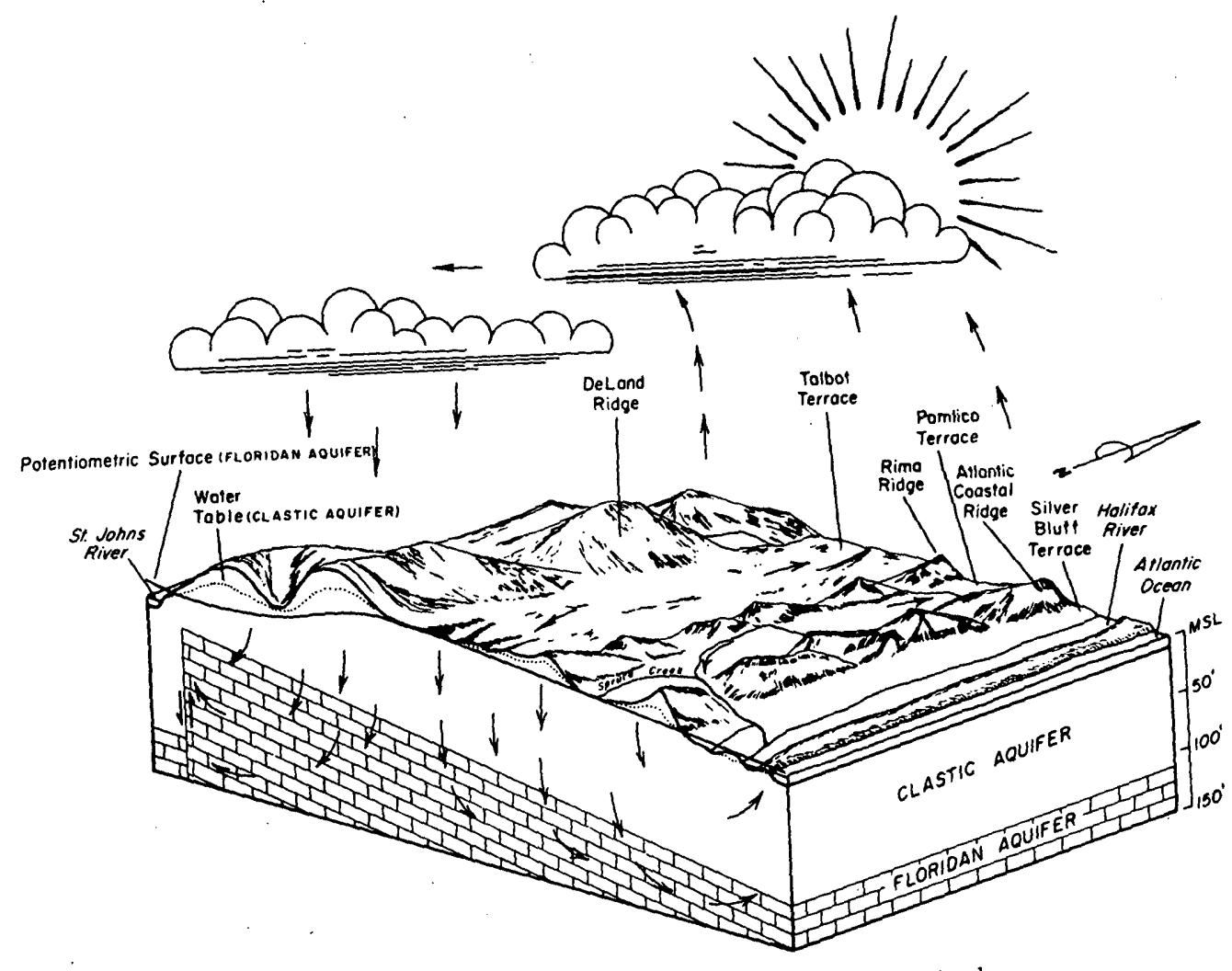

Figure 2.-Block diagram of part of Volusia County providing generalize
vitew the hydrologic system (from Knochenmus and Beard,

view of the hy
1971 , fig. 5). 
retard the vertical movement of water within the Floridan aquifer. One particularly thick hard layer appears to be continuous over large areas (Wyrick, 1960, fig. 14), and "acts as a confining bed that divides the aquifer into an upper and lower part" (Knochenmus and Beard, 1971, p. 9). This layer dips eastward from about 200 feet below land surface under the Deland Ridge to about 250 feet below land surface near the coast.

For purposes of this study and development of aquifer parameters, this layer is considered the base of the aquifer modeled. This assumption is not entirely realistic because undoubtedly some movement of water occurs between the upper and lower parts of the Floridan aquifer in the real system, however restrictive to flow the dense layer may be. Nevertheless, the upper Floridan aquifer is considered the principal waterbearing zone, and future supply wells are expected to be finished above the dense layer shown in Wyrick's figure 14.

Local rainfall is the source of Volusia County's freshwater (Knochenmus and Beard, 1971, p. 13). The rate of recharge to the Floridan aquifer is controlled by the vertical hydraulic conductivity and thickness of the confining layer between the water-table and. Floridan aquifers, and the head difference between the two aquifers. Knochenmus and Beard (1971, p. 9) report that great variation in vertical hydraulic conductivity apparently occurs from site to site on a particular terrace or ridge, as well as between sites within different physiographic divisions because of the discontinuity of less permeable material comprising the confining layer. Field observation and laboratory permeability analyses of core samples from the part of the water-table aquifer considered the confining layer 
in the central wetlands tends to confirm this hypothesis. Little or no clay was encountered at some test sites, while clay beds several feet thick were encountered at others.

The head difference between the water-table and Floridan aquifers also varies considerably, and is greater in ridge areas than in terrace areas. The ridges are good recharge areas mainly because of their topographic relief (Knochenmus and Beard, 1971, p. 13), which results in a relatively thick unsaturated zone to provide storage capacity for rainfa11.

On the terraces, particularly the Talbot terrace, the unsaturated zone is thin or missing. The high potentiometric surfaces of the watertable and Floridan aquifers in the central wetlands area between the Deland and Rima ridges do not allow much additional storage before runoff begins. Thus, water potentially available for recharge to the Floridan aquifer is lost to runoff. For purposes of this report, subsurface runoff, or base flow, is also included in the term "runoff".

Discharge areas for the Floridan aquifer in Volusia County exist along the Atlantic coast to the east, along the St. Johns River to the west and south, and along parts of Little Haw and Middle Haw Creeks to the northwest. These discharge areas expand and contract in response to changes in hydrologic conditions.

The gradient between the upper and lower parts of the Floridan aquifer is downward in central Volusia County and upward in the discharge areas, on the basis of a few test wells. As previously mentioned, the 
extent to which movement of water between the upper and lower parts of the Floridan aquifer occurs is not known. The net exchange of water is assumed minimal because of the dense dolomitic layer separating the upper and lower zones, and the fact that the gradient between the upper and lower zones is in opposite directions in recharge and discharge areas. Chloride concentration in water in the Floridan aquifer generally increases with depth in the aquifer. Concentrations exceeding 1,000 milligrams per liter may be expected at about 700 feet below mean sea level (Wyrick, 1960, fig. 22) at the well-field property.

In summary, the generalized picture, or conceptual model, of Volusia County's hydrologic system is as follows: Water moves downward to the Floridan aquifer in the central area, primarily under the ridges, with minor amounts under the wetlands; it then flows laterally away from the central area, down gradient in the Floridan aquifer, to discharge areas to the east, west, north, and south.

SUITABILITY AND APPLICATION OF THE DIGITAL MODEL

The Pinder-Trescott digital model is a Fortran computer program that calculates the response of a confined or unconfined aquifer to simulated stresses imposed on the aquifer. The stresses may be in the form of pumping from wells, recharge, evapotranspiration, leakage from a confining bed, lake, or stream, natural gradients, or a combination of the above, depending on the particular program options selected.

A rectangular grid is superimposed on a map of the area to be modeled, dividing the area into a series of blocks, or nodes. Hydrologic parameters necessary for describing the movement of water through the 
system for each node are entered into the computer. The program uses an iterative, alternating-direction implicit procedure to solve the twodimensional ground-water flow equations for the head values at each node as a function of time and space. That is, the computer program will provide a printout in digital form of the potentiometric surface of the modeled aquifer at the end of discrete time perfods, or when steady state is reached.

The model can simulate impermeable boundaries, constant-flux boundaries or constant-head boundaries. Constant-head boundaries may recharge water to or discharge water from the aquifer, depending on the direction of the gradient at that boundary.

The capabilities of the digital model as outlined above seemed generally adequate to simulate the conceptual model of an operating well field in central Volusia County. The model area, overlain by the final grid, is shown in figure 3. (After model calibration, the grid size was refined from 26 rows by 27 columns to a final grid size of 59 rows by 48 columns.) A variable-spaced grid dividing the area into nodes that are multiples of one minute of latitude by one minute of longitude was selected. This allows nodes in the well-field area, where the best definition of head changes is desired, to be smaller than those in outlying areas. A larger area can therefore be modeled, while keeping the number of nodes within manageable limits. If the area modeled is large enough, then the effects of simulated well-field pumping will not cause measurable changes in head at the boundaries, a desirable situation because none of the three possible boundary conditions is entirely realistic tor Volusia County when subjected to pumping stresses. 


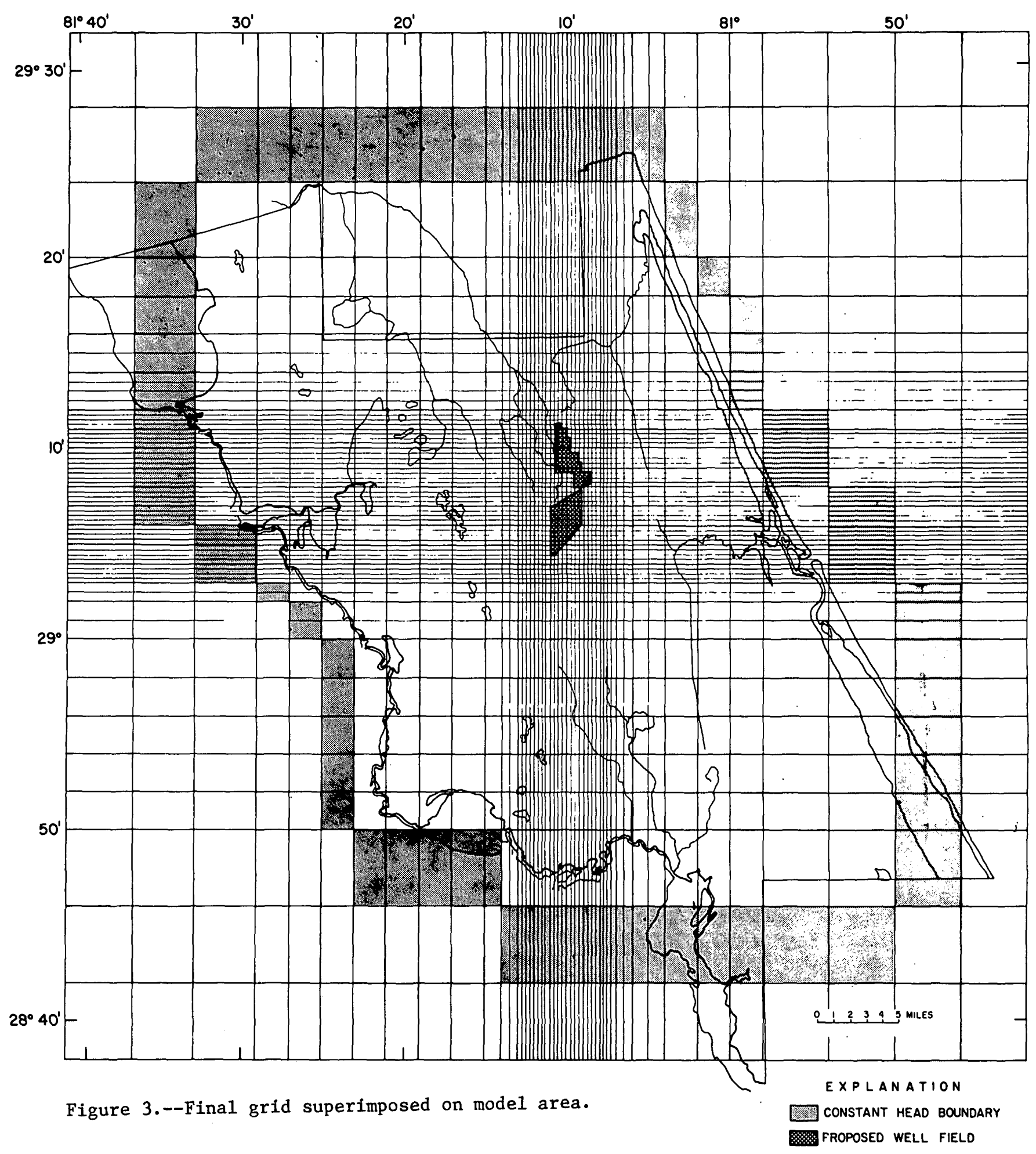




\section{Mode1 Boundaries}

The Saint Johns River and the Atlantic Ocean were selected as west and east boundaries of the model, respectively, because as discharge areas, they appear to be natural hydrologic boundaries of the Floridan aquifer in Volusia County. They also enclosed an area large enough so that the effects of simulated pumping from the Floridan aquifer in central Volusia were not likely to cause measurable head changes at those boundaries. The head and the flux vary seasonally along each boundary under natural conditions, but the long term average of each may be considered constant. Because the average head along the Atlantic and the Saint Johns is considerably easier to estimate than the flux, constant-head boundaries were used for those boundaries in the model.

The north model boundary, and the south model boundary not a part of the Saint Johns River, were somewhat arbitrarily chosen. Again the object was to include enough area so that the effects of simulated well-field pumping would not cause measurable head changes at these boundaries. Constant-head boundaries can then be used in the model, since, assuming the model is accurate, average head values in the real system would not change measureably during well-field pumping. Natural gradients at the north and south boundaries indicate that some ground-water flow occurs across them, but as with the east and west boundaries, heads at each node were easier to estimate than flux. Constant-head nodes in the model are designed with an infinite storage capacity so that they may absorb or provide water as dictated by gradients to or from such nodes without altering head. 


\section{Hydrologic Data Input}

Input parameters that describe the hydrologic system at each node are required for simulation with the model. For the leaky confined aquifer system in Volusia County, the necessary hydrologic input parameters are: (1) the altitude of the unstressed potentiometric surface of the watertable aquifer; (2) the altitude of the unstressed potentiometric surface of the Floridan aquifer; (3) the vertical hydraulic conductivity of the confining layer; (4) the thickness of the confining layer; and (5) the transmissivity of the Floridan aquifer.

It was judged that the project objectives could best be met by generating projected long-term average conditions in the Floridan aquifer under various stress conditions. Therefore, computer simulations were run to a steady-state. This was done to facilitate comparison of wellfield design alternatives without the interference of transient factors such as climatic variations.

Estimates of average values for those input parameters that vary seasonally were used at each node for the steady-state analyses. An initial grid of 26 rows by 27 columns was used for estimating input parameters at each node, and for calibration. The November 1966 potentiometric surface map of the Floridan aquifer shown in figure 4 (Knochenmus and Beard, 1971, fig. 15) was used to obtain initial Floridan aquifer head values. The 26-row by 27 -column grid was superimposed on this map, and numerical estimates of the head at each node thus defined were made (fig. 5). Later potentiometric surface maps are available, but the November 1966 map is probably a better approximation of average head 


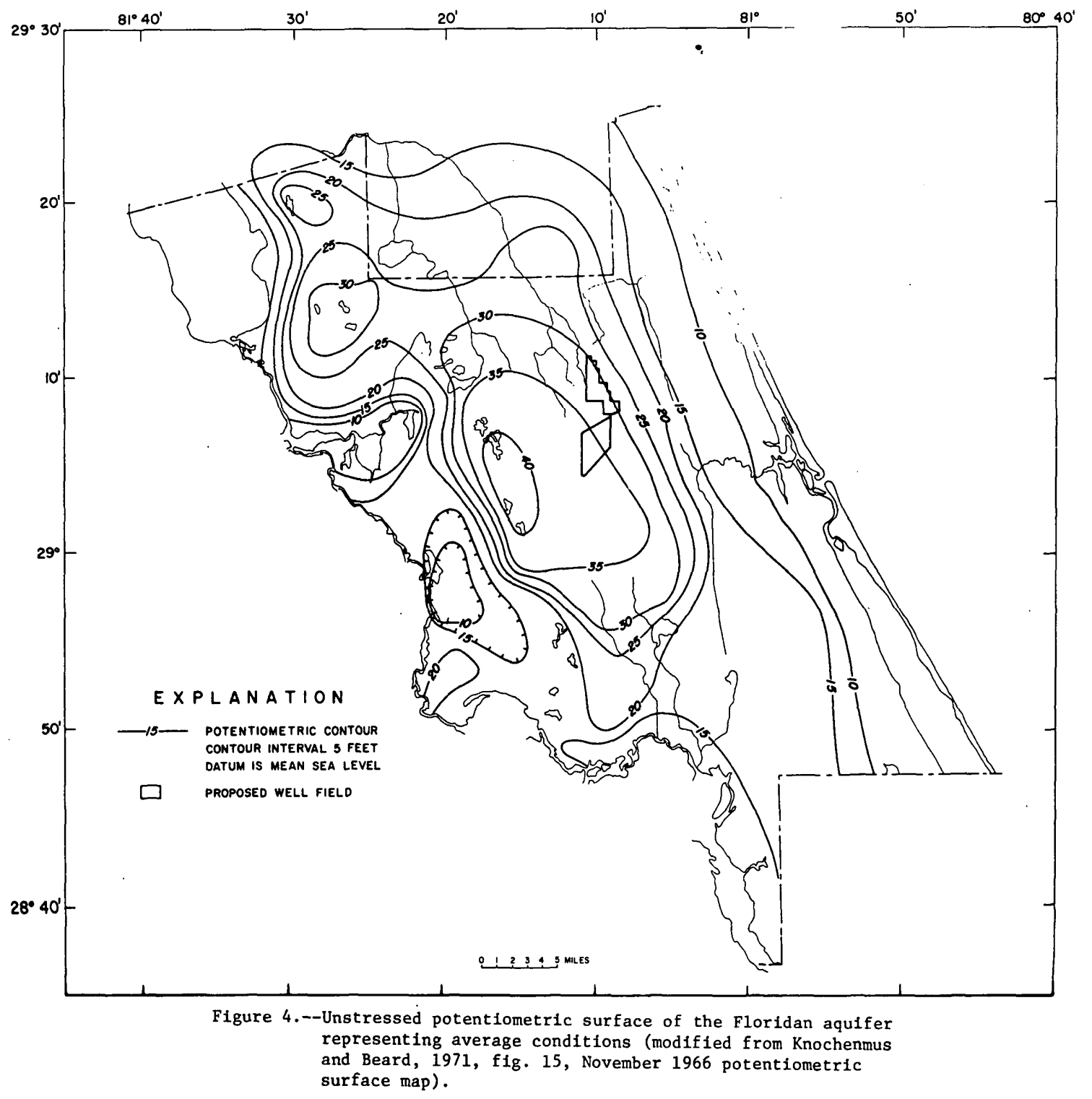




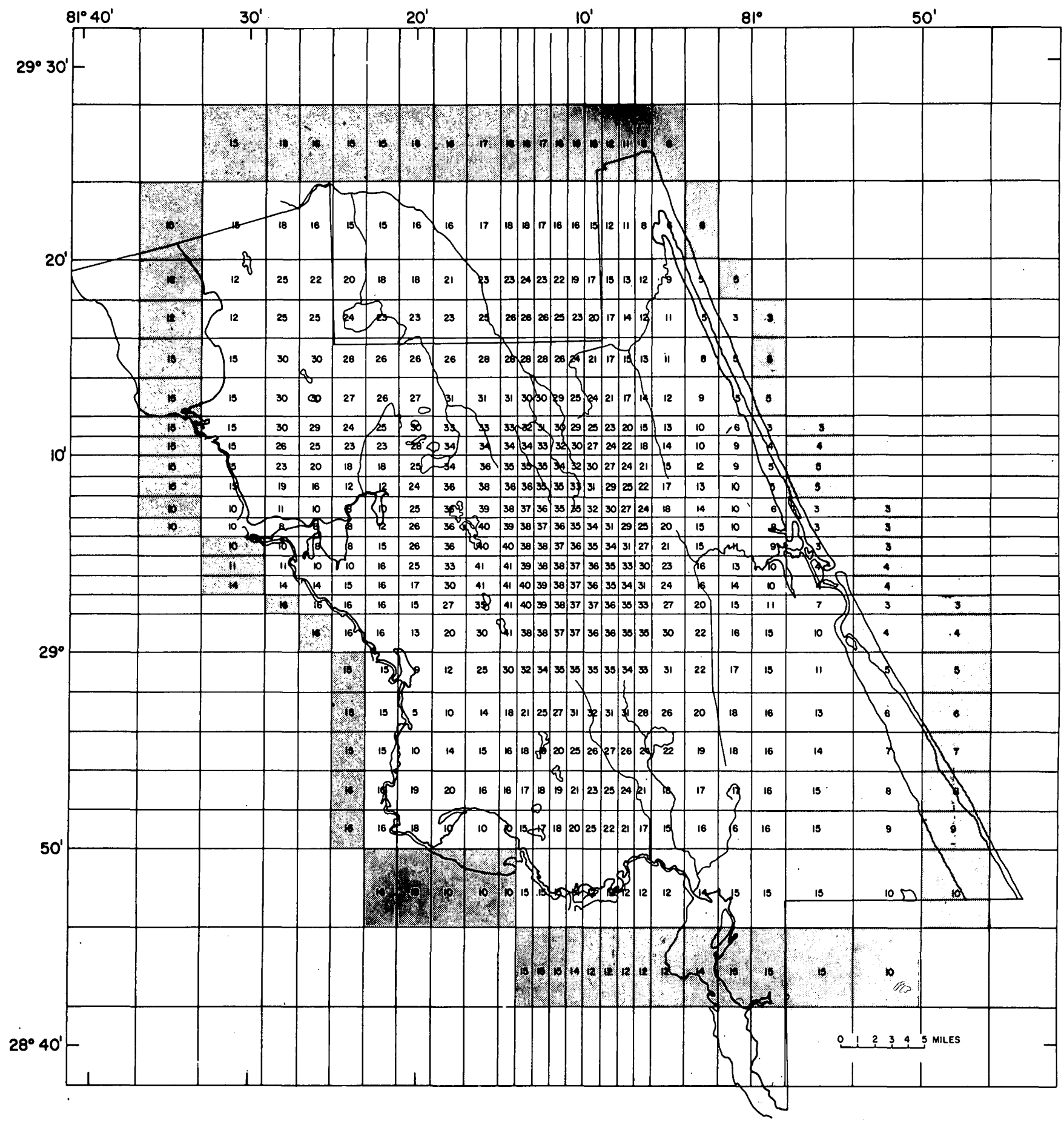

Figure 5.--Estimated altitude of the potentiometric surface of the Floridan aquifer for each node, in feet. Shaded area represents constant-head nodes. 
conditions than subsequent maps. All the more recent maps are for May of different years, usually the month of lowest water levels.

Numerical values for the head in the water-table aquifer (fig. 6) were obtained by outlining the 26 -row by 27 -column grid on $7 \frac{1}{2}$-minute topographic maps. Then, using lake and stream elevation, swamp symbol, and topography, an average water-table altitude at each node was estimated. No actual water-level measurements were used.

Transmissivity data for the Floridan aquifer in the modeled area are sparse relative to the number of nodes for which values are needed. Enough data were available from previous investigations (Wyrick, 1960, table 3; Bermes and others, 1963, table 5) to indicate the order of magnitude that might be expected in the area. Initially, a uniform value of 26,736 feet square per day was used for every node. Transmissivity variations, developed during calibration, will be discussed in the next section.

Hydraulic conductivity and thickness data for the confining layer between the water-table and Floridan aquifers are also lacking relative to the number of nodes. Only laboratory permeabilities from core samples taken at nine core-hole sites in the central wetlands are available. Each sample chosen for permeability analysis was from material that appeared to be the least permeable at a particular site. The actual field hydraulic conductivity over an entire vertical section in the model area, even at the nine core-hole sites, is unknown. The thickness of material considered "confining layer" could be obtained from continuous core at the drill sites. However, the model uses leakance (the quotient of hydraulic 


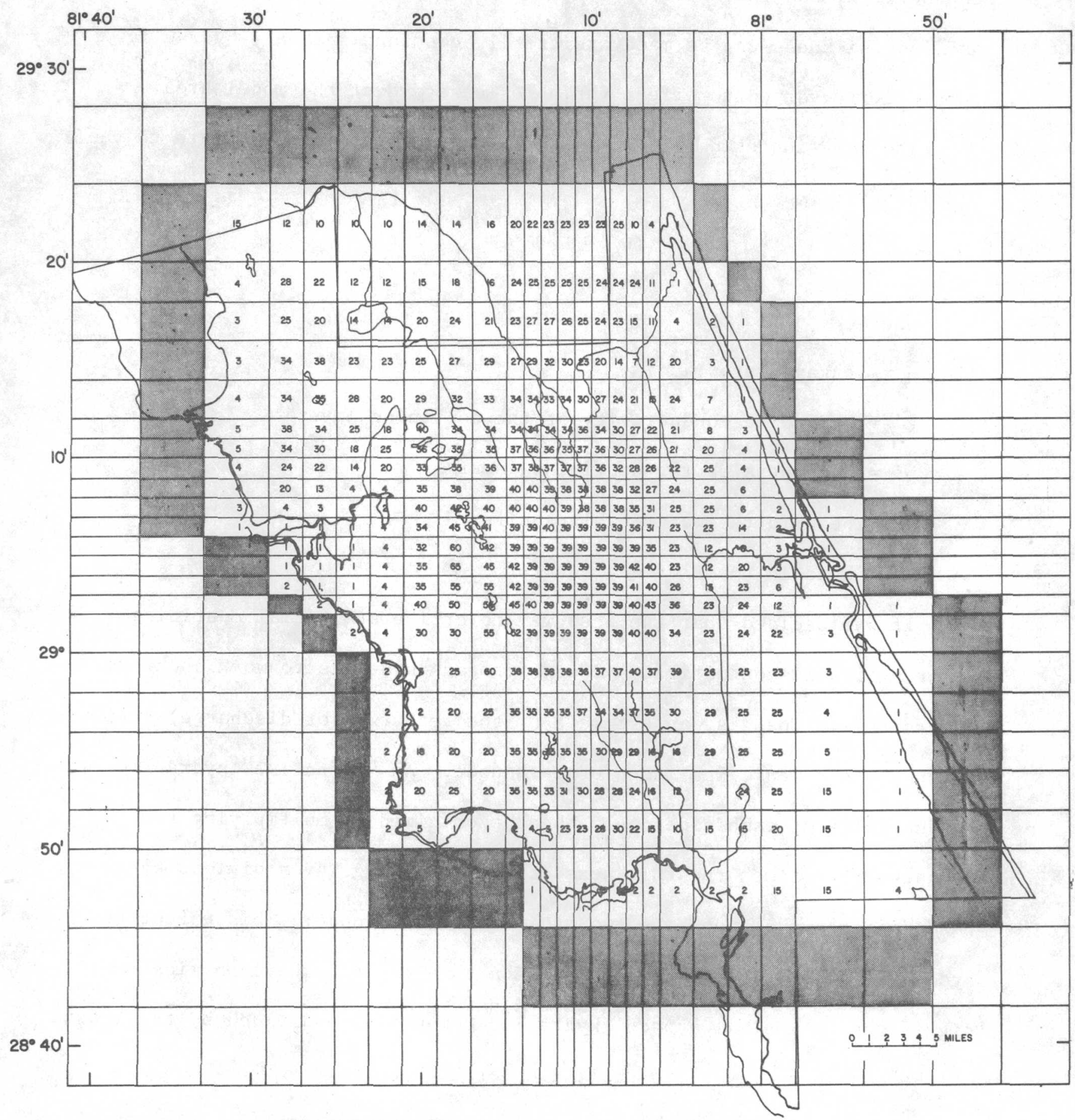

Figure 6.--Estimated altitude of the potentiometric surface of the water table for each node, in feet. Shaded area represents constanthead nodes. 
conductivity and thickness) in the calculation of leakage rate at each node so thickness can be made arbitrarily constant and only hydraulic conductivity varied to effect variable leakage over the model area.

The equation used by the mode] to calculate the leakage rate to the Floridan is:

$$
q=\frac{k^{\prime}}{b^{\prime}}\left(H_{s}-H_{f}\right)
$$

where

$q=$ leakage rate

$k^{\prime}=$ hydraulic conductivity of the confining layer

$b^{\prime}=$ thickness of the confining layer

$\mathrm{H}_{\mathrm{S}}=$ head in the water-table aquifer

$\mathrm{H}_{\mathrm{f}}=$ head in the Floridan aquifer

It was decided that the best way to arrive at initial confininglayer hydraulic conductivity values for each node was to work backward toward them. That is, an estimate of the recharge (or discharge) rate, in inches per year, was made for each node. An "effective" hydraulic conductivity at each node could then be obtained by multiplying the recharge rate times the thickness of the confining layer divided by the head difference between the two aquifers at each node. This effective hydraulic conductivity by itself does not necessarily have physical significance. Only leakance, hydraulic conductivity divided by thickness of the confining layer, is realistic for each node.

The basis for estimating initial recharge and discharge rates over the model area was a map of average annual rainfall and runoff for Volusia County by Knochenmus (1968, fig. 2). The map provides rainfall and a range 
of runoff values for different areas of the county. Algebraically combining rainfall, runoff, and estimates of evapotranspiration left a residual range of recharge values for each node from which a single value was selected.

A basic premise, or assumption, of this study is that after a well field in central Volusia County has been operating long enough to reach steady state, additional recharge over and above that which occurs under unstressed conditions will be induced over the area of influence of the well field because of the increased vertical gradient between the upper and lower aquifers. The additional water to supply the well field must come from evapotranspiration and runoff since rainfall is constant on the average. Before this additional water can get into the Floridan aquifer, it must first get into the water-table aquifer; thus, additional storage space above the water table will be required. Under unstressed conditions, the potentiometric surface of the water table is about at land surface in the area. Therefore, if additional storage space is to be created, the average altitude of the water table will have to drop. It seems reasonable that this will occur: As pumping continues during the dry season of a given year, leakage to the Floridan will come primarily from storage in the watertable aquifer, so the water table will decline at a greater rate than it would have if wells were not being pumped. More storage space would be available since the water table would be lower at the start of the rainy season with a well field operating than without a well field operating. It follows that the water table will rise during the rainy season assuming an average steady-state water-table condition, and that the water table falls during the dry season. 
The model has a shortcoming regarding the water table. It holds the altitude of the water-table constant during a simulation period instead of allowing it to reach a new equilibrium position in response to pumping from the Floridan. Thus, the simulated head difference between the two aquifers may be unrealistically high near the center of pumping, allowing too much simulated leakage to occur unless leakage is somehow restricted.

The leakage can be restricted in the model in the following way (P. C. Trescott, oral commun., 1973): The model has a confined-unconfined option to be used when modeling an aquifer that changes from confined to unconfined conditions under stress; when the stressed potentiometric surface of a confined aquifer drops below the top of that aquifer over an area, it becomes unconfined in that area. Assuming leakage from an overlying water-table aquifer, when the confined aquifer becomes unconfined, the head driving the leakage becomes the difference between the altitude of the water table and the altitude of the top of the formerly confined aquifer, rather than the difference between the two potentiometric surfaces.

In Volusia County, there is little possibility that the altitude of the potentiometric surface of the Floridan aquifer will drop below the top of the aquifer under pumping conditions; but by entering an "artificial". top-of-the-aquifer altitude into the model at nodes in central Volusia County, leakage can be restricted. The leakage rate becomes fixed if simulated pumping causes the potentinmetric surface to drop below the artificial top-of-the-aquifer altitude at a particular node. The difference between the potentiometric surfaces of the water table and the Floridan aquifers can continue to increase to a steady state, but the 
leakage is computed based on the difference between the altitudes of the water table and the top of the aquifer.

In other words, when the head in the Floridan aquifer $\left(\mathrm{H}_{\mathrm{f}}\right)$ becomes less than the artificial top-of-the-aquifer altitude (A), the equation for leakage in the model becomes

$$
q=\frac{k^{\prime}}{b^{\prime}}\left(H_{s}-A\right)
$$

The result, if not the means, of treating leakage in the model seems compatible with what will happen in the real system. In the real system, the long-term average annual leakage at steady state can be no more than the long-term average amount of water available to leak on an annual basis. Over a particular area in the real system corresponding to a node in the model, the water table will adjust to some long-term average altitude such that the resulting gradient, and the hydraulic conductivity and thickness of the confining layer in that area will not allow leakage to exceed a certain long-term average rate. (This assumes negligible lateral flow toward the well field in the water-table aquifer, which seems reasonable since vertical gradients will be orders of magnitude greater than any lateral gradients due to a possible cone of depression in the water-table aquifer.)

An estimate of the long-term average amount of water available to leak on an annual basis was arrived at in the following way: Average annual rainfall in the area is 52 inches. Under unstressed conditions, average annual evapotranspiration is estimated to be 38 inches, based on water budget studies in the Green Swamp (Pride and others, 1966, table 14; and table 18), an area in central Florida hydrologically similar to central 
Volusia County. This leaves 14 inches per year to be divided between runoff and recharge. Average annual runoff in the area amounts to about 11 inches per year based on streamflow records of Little Haw Creek, the Tomoka River, and Spruce Creek. The residual 3 inches per year is recharge.

The judgment was made to assume that the principal source of induced recharge will be runoff. The reason for this is that it is not known how much evapotranspiration would be reduced for a given drop in water-table altitude; it is not even known what the drop in water-table altitude will be. Undoubtedly, some water would be salvaged from evapotranspiration as a result of a long-term average drop in water-table altitude. But it was thought better to omit evapotranspiration as a source of induced recharge, and ensure that any analysis will be conservative, rather than to try to first estimate the drop in long-term average water-table altitude, and then estimate the amount of evapotranspiration salvage that would result from the water-table change. If all of the runoff from a particular area were diverted to recharge in a given year, an additional 11 inches would be induced, making 14 inches the maximum available for leakage. It is improbable that all of the runoff would be diverted to recharge on the average over the area of influence of the well field. Rainfall is unevenly distributed over a year; on the average 59 percent of annual rainfall occurs in June, July, August, and September. It is likely, with a well field operating, that the water table would continue to build up to land surface and allow runoff to occur over much of the area of influence of the well field, as it does in the unstressed condition. Also, when the rainfall rate exceeds the infiltration capacity of the soil, runoff will 
occur. Nevertheless, since at least 14 inches per year is potentially available to leak, 14 inches per year was chosen as the upper limit to leakage.

\section{CALIBRATION PROCEDURE}

Before pumping can be realistically simulated with the model, calibration to demonstrate that the model is representative of the real system is necessary. Calibration was accomplished by trial-and-error adjustment of input parameters until the unstressed potentiometric surface of the Floridan aquifer could be reproduced by the model. Using the grid of 26 rows by 27 columns, a series of computer runs were made in which transmissivity of the Floridan aquifer and (or) hydraulic conductivity of the confining layer, and (or) head values, were adjusted in successive runs, based on the output from each previous run. Calibration was considered to be adequate when the steady-state modeled potentiometric surface of the Floridan aquifer was everywhere within 1 foot of the assumed initial steady-state conditions.

Transmissivity values over the model area were changed the most during calibration. Hydraulic conductivity values, derived from recharge estimates, also required extensive changes, although the range of possible variation at each node was limited to a certain extent by the physiographic region in which the node was located. Typical printouts during the calibration process would show areas of head rises and areas of head declines in the artesian aquifer. Modeled head rises at steady state result from an excess of inflow over outflow. Conversely, modeled declines in head result from an excess of outflow over inflow. To reduce 
head rises, transmissivities must be increased, or leakage reduced (assuming the head difference is judged to be accurate). To reduce declines, transmissivities must be decreased or leakage increased (again assuming head is accurate).

It is assumed that model transmissivities (fig. 7) represent the water-transmicting characteristics of the upper part of the Floridan aquifer, above the dense layer of dolomitic limestone previously mentioned that is believed to separate the aquifer into an upper and lower part. Starting with a uniform transmissivity of 26,736 feet square per day, it was necessary to reduce transmissivity values in the center of the modeled area, and raise them elsewhere. Relatively high transmissivities were required in the areas around Blue Springs and Ponce de Leon Springs. This is not surprising, since these springs discharge 160 cubic feet per second and 30 cubic feet per second, respectively, with relatively shallow cones of depression in the potentiometric surface.

Hydraulic conductivity values of the confining layer in general were lowered during the calibration process. Figure 8 shows the final recharge figures for each node, from which the computer program calculated hydraulic conductivity values.

The two large springs previously mentioned were simulated in the model by discharging wells. Existing well fields were not included in the model. When a central well field is constructed, pumping from the Daytona Beach well field, the only well field within the area of influence of the central well field, would be cut back substantially or eliminated altogether. 


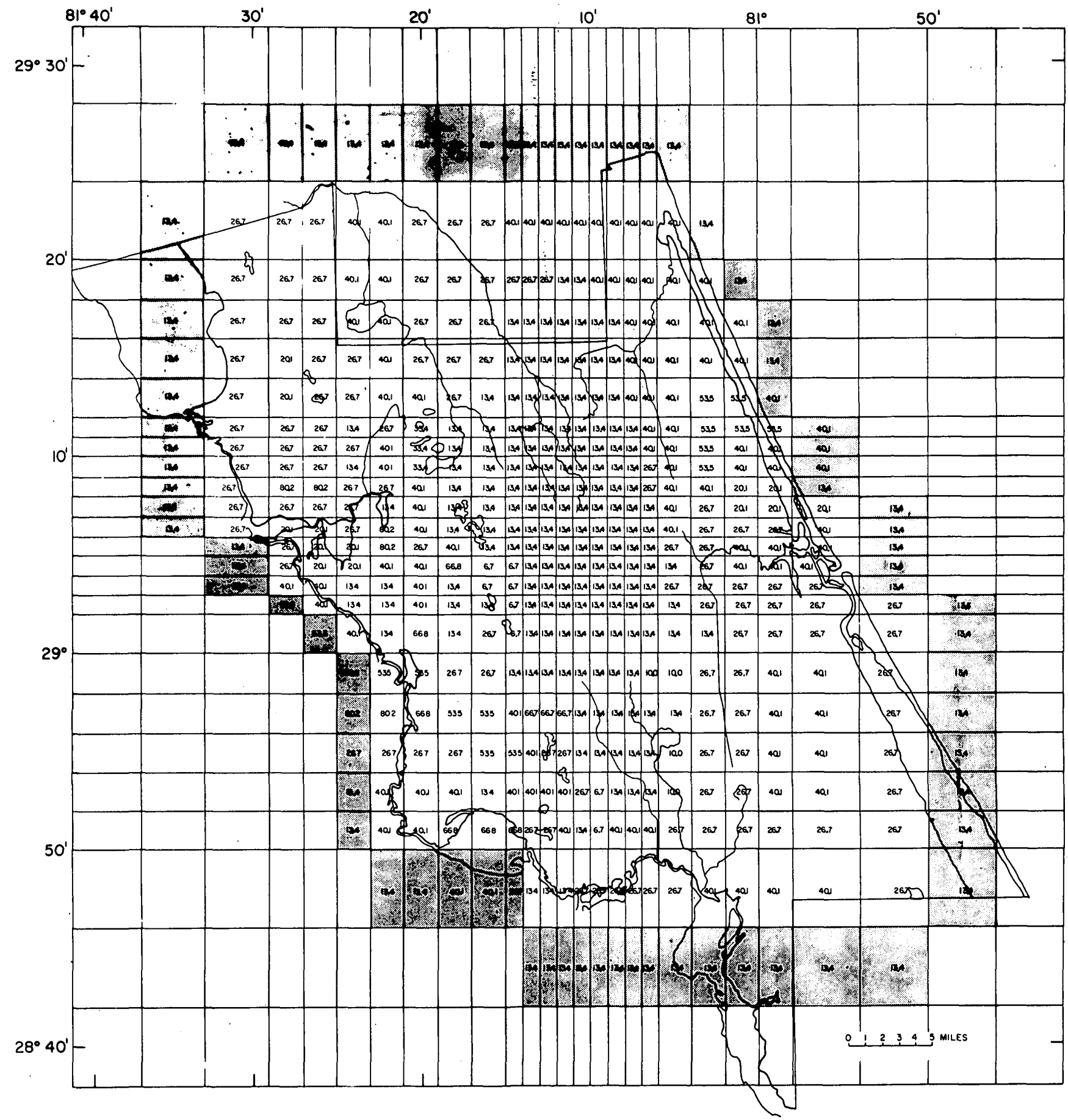

Figure 7.--Estimated transmissivity of the Floridan aquifer in thousands of feet square per day. Shaded area represents constant-head nodes. 


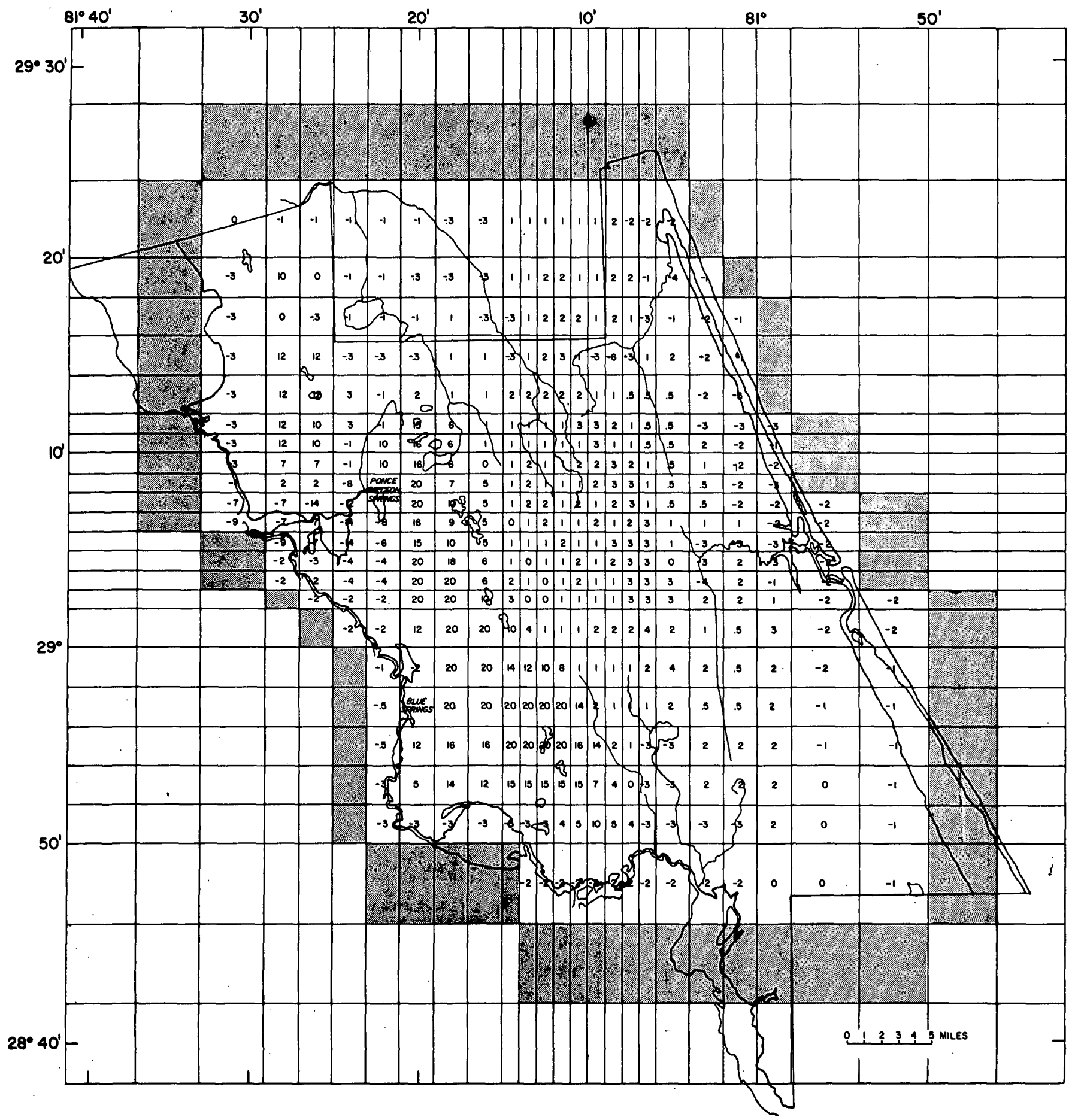

Figure 8.--Estimated recharge for each node, in inches per year (the basis for hydraulic conductivity input). Shaded area represents constant-head nodes. Cross-hatched area represents discharge area in the model. 
In addition to adjustments of transmissivity and confining-layer hydraulic conductivity during calibration, increases in discharge area were necessary to eliminate problems of buildup of the potentiometric surface in areas near the boundaries. This was done by reassessing the direction of leakage in many of the nodes near the boundaries. Due to the relatively large node size, and hence areal variation in altitude of the water table and potentiometric surface of the Floridan aquifer, considerable leeway was possible in estimating head values. By trial and error, heads were reversed in some nodes that previously had downward gradients.

After calibration, the grid size was expanded from 26 rows by 27 columns to 59 rows by 48 columns. To do this, nodes of one minute of latitude by one minute of longitude in the center of the model area were reduced to nodes of one-quarter minute of latitude by one-quarter minute of longtitude. In Volusia County, a one-minute section ị 1.143 square miles. Hence, in the area of interest, each node of the final grid represents 0.071 square mile. Input parameters for each one-minute section thus divided were used in the resulting quarter-mile sections.

The model provides another means of evaluating the general representativeness of the input parameters. It prints out a mass balance of all inputs and outputs over the entire model area as summarized in table 1. The average recharge rate over the model area can be determined by dividing the total downward leakage rate by the model area (1,407 square miles) and converting to inches per year. The result is 3.01 inches per year, a reasonable figure for average recharge in Volusia County. Total discharge 
Table 1.--Mass balance for unstressed conditions.

$\begin{array}{lcccc}\text { Sources } & \begin{array}{c}\text { Cubic feet } \\ \text { per second }\end{array} & \frac{\text { Discharges }}{\text { Cubic feet }} & \text { per second } \\ \text { Inflow at boundaries } & 76 & & \text { Outflow at boundaries } & 40 \\ \text { Downward leakage } & 312 & \begin{array}{c}\text { Upward leakage (includ- } \\ \text { ing spring discharge) }\end{array} & 348\end{array}$

Net leakage due to gradients at beginning of simulation period (excluding spring discharge)

Net leakage due to gradients at end of 155 simulation period (excluding spring discharge) 
for the model area resulting from upward leakage and spring discharge, calculated as above, is 3.36 inches per year. The imbalance between upward leakage plus spring discharge over recharge at steady state is' primarily accounted for, according to the model, by water that flows in across the west boundary to be discharged at Blue Springs. of the 76 cubic feet per second shown in the mass balance as inflow at the boundaries, 59 cubic feet per second occurs at the three constant-head nodes adjacent to Blue Springs. The two leakage terms at the bottom of table 1 , net leakage due to gradients (excluding spring discharge) at the beginning and at the end of the simulation period, are nearly equal; this would be expected when the final potentiometric surface of the Floridan aquifer at the end of the simulation period is nearly the same as the initial potentiometric surface.

What can be said about the model after calibration is that a set of input parameters has been determined that, taken collectively, seems to simulate the conceptual model of the hydrologic system and is of reasonable order of magnitude, based on available data and judgment. There is no practical way to determine whether or not the parameters selected for each node are actually "right." Undoubtedly, some are more accurate than others, and the model can certainly be refined if more data become available. 


\section{RESULTS}

A series of computer runs were made simulating pumping from wells in the well-field property. Various combinations of well-field design and pumping rates were experimented with to try to obtain the most water with the least drawdown. The more useful of these runs are documented in this section.

Figure 9 shows the predicted steady-state cone of depression that would result from pumping each of 67 wells at a rate of about 200 gallons per minute with a maximum allowable leakage rate of 14 inches per year for a total withdrawal rate of 20 million gallons per day. The pattern of well locations and drawdowns at the deepest part of the cone are shown in figure 10. The estimated area of influence of the cone of depression is 150 square miles resulting in an average induced leakage rate of 2.8 inches per year. Figure 11 shows the result of superimposing this cone of depression (fig. 9), on the unstressed potentiometric surface of the Floridan aquifer shown in figure 4. The model allows one well. per node. For a node with a well in it, the model computes an average drawdown over the entire area of the node, rather than the drawdown at the woll. 'lhe conter of the cone of depression in figure 11, therefore, represints an average altitude between 5 and 10 feet above sea level in the area of the pumped wells. But it is possible that drawdowns at wells at or near the center of the cone of depression will be below mean sea level.

In an idealized static coastal situation where the head in the aquifer on the saltwater side of the freshwater-saltwater interface is 


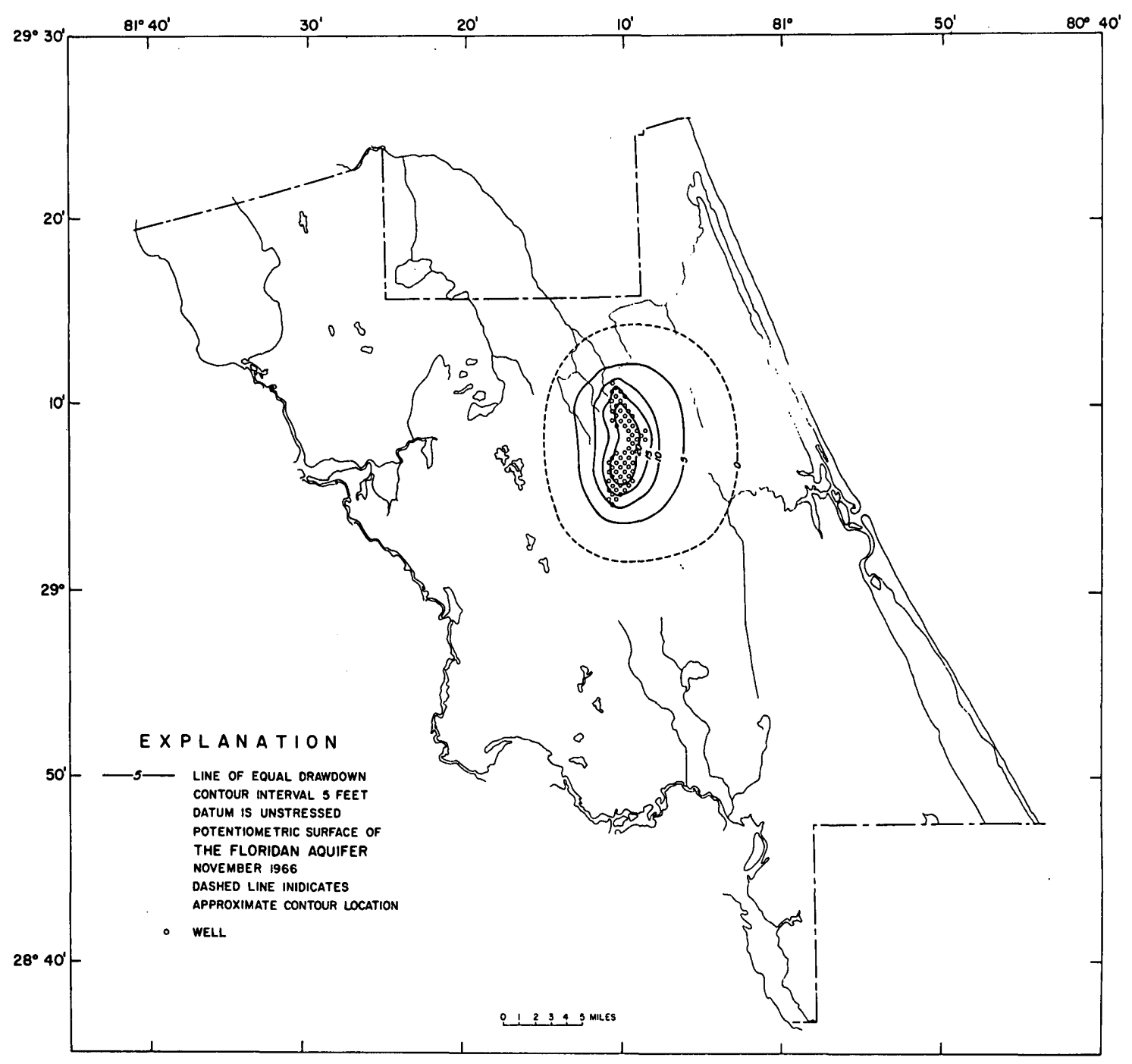

Figure 9.--Steady-stage cone of depression due to simulated pumping of 20 million gallons per day; leakage limited to a maximum of 14 Inches per year in the well-field area. 



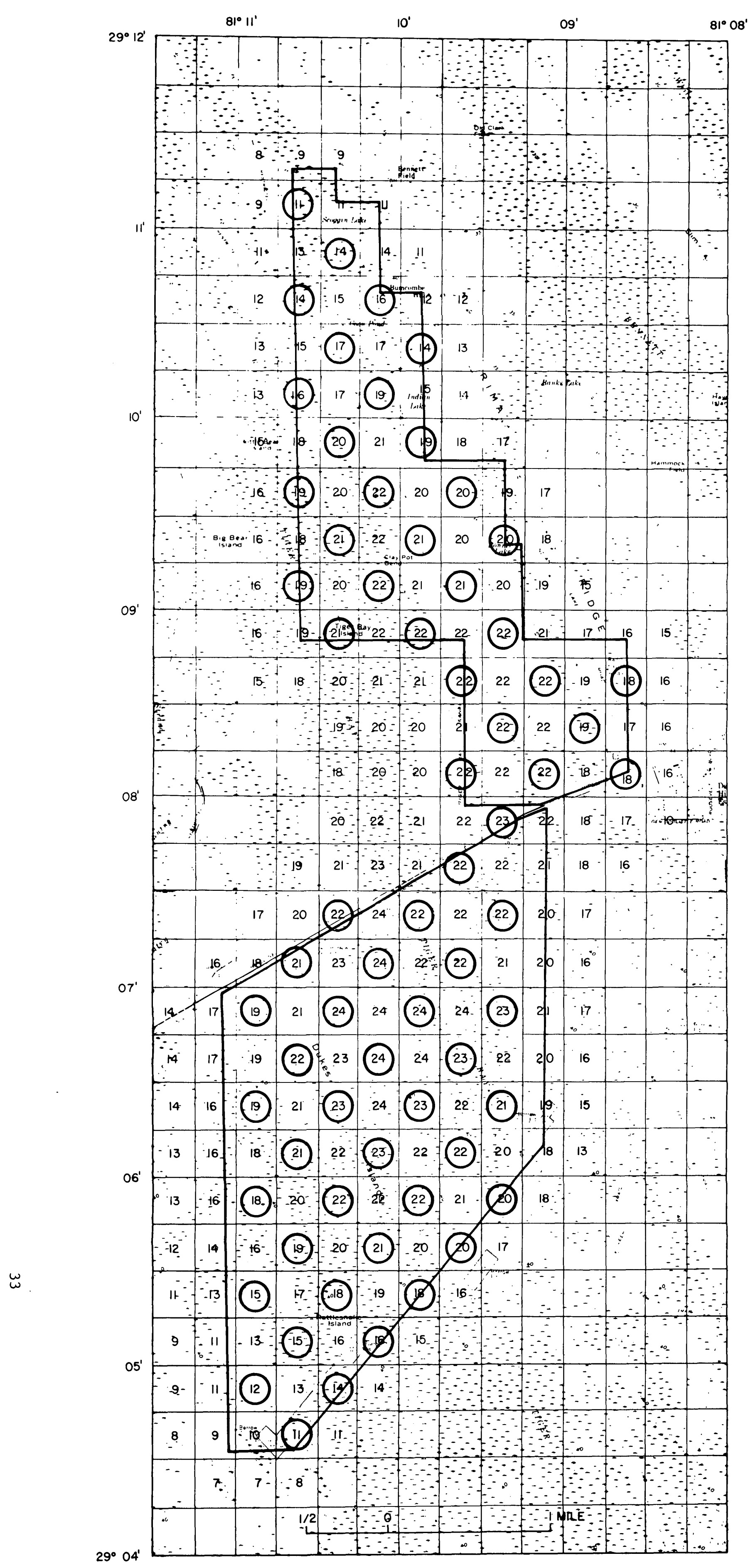

Figure 10. Steady-state drawdown values for each node near the center 列 of pumping due to limited to a maximum of per day from 67 wells. 



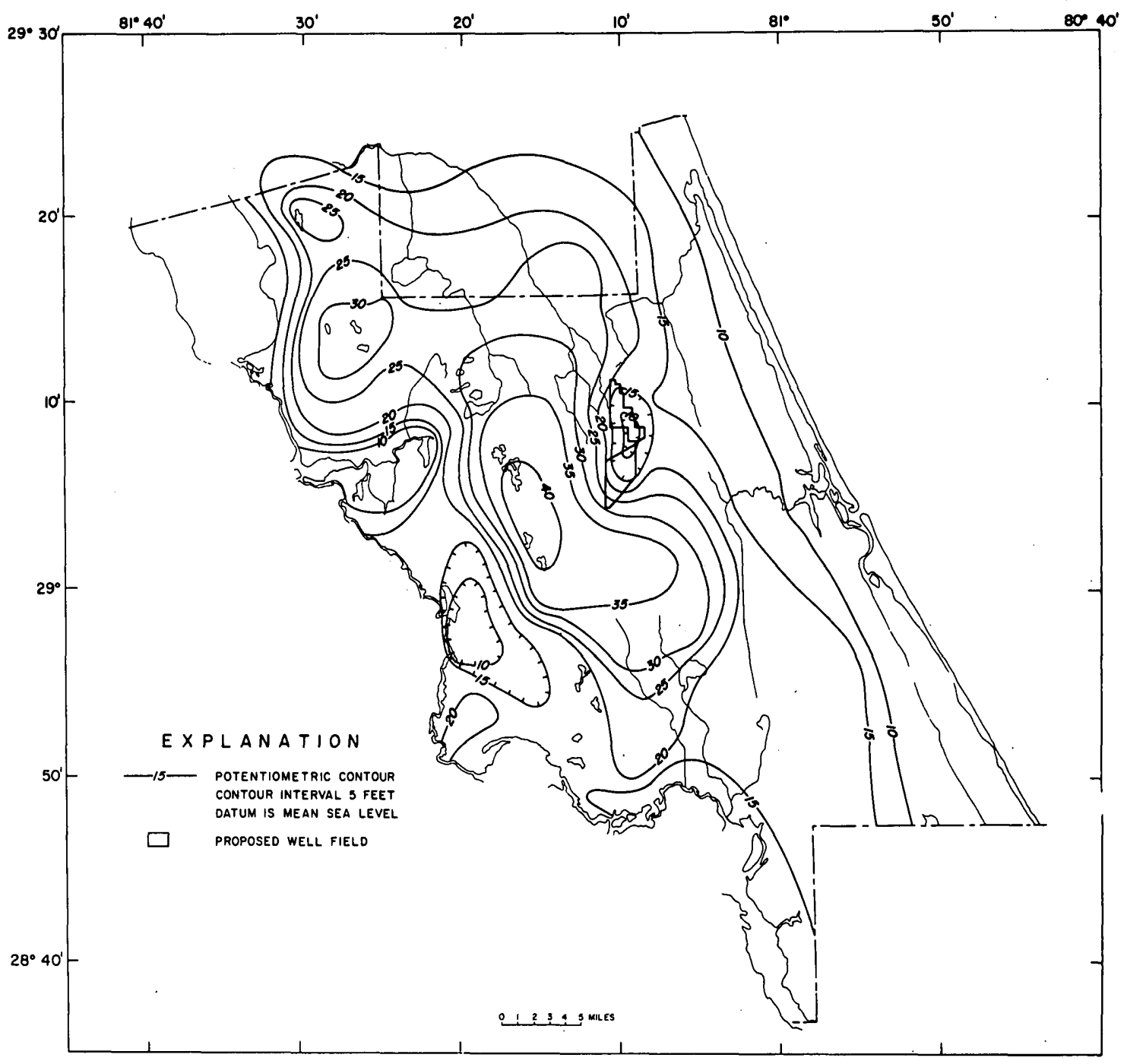

Figure 11.--Potentiometric surface resulting from cone of depression from figure 9 (20 million gallons per day, maximum allowable leakage 14 inches per year) superimposed on unstressed potentiometric surface of figure 4 . 
sea level, that altitude (or slightly above sea level, allowing for well penetration of the aquifer) is the theoretical minimum to which a cone of depression can be lowered with no potential for saltwater intrusion into the pumped zone. However, from head data obtained from a deep well penetrating the freshwater-saltwater interface in central Volusia County near the Deland Ridge, it is inferred that the head at the freshwater-saltwater interface at the proposed well-field site is several feet above sea level. Thus, assuming a withdrawal rate of 20 million gallons per day and an average elevation of the potentiometric surface at the center of the cone of depression of 5 to 10 feet above sea level, a gradient from the zone of the aquifer containing salty water to the pumped zone could exist, depending on the head at the freshwatersaltwater interface. But it is believed that layers of relátively low permeability between the interface and the pumped zone would prevent the actual migration of salty water to the pumped zone, given the pumping and water-level conditions stated above.

Computer simulations were made with the well-field configuration of figure 10 and total withdrawal rates of 40,30 , and 25 million gallons per day. Altitudes at the center of the cones of depression generated in these simulations were below mean sea level.

Well-field development undoubtedly will depend as much on economics as on hydrology. Sixty-seven wells, each pumping 200 gallons per minute, probably are not as practical, economically, as a smaller number of wells of greater yield. Figures 12 and 13 show the drawdowns and wel1 locations 


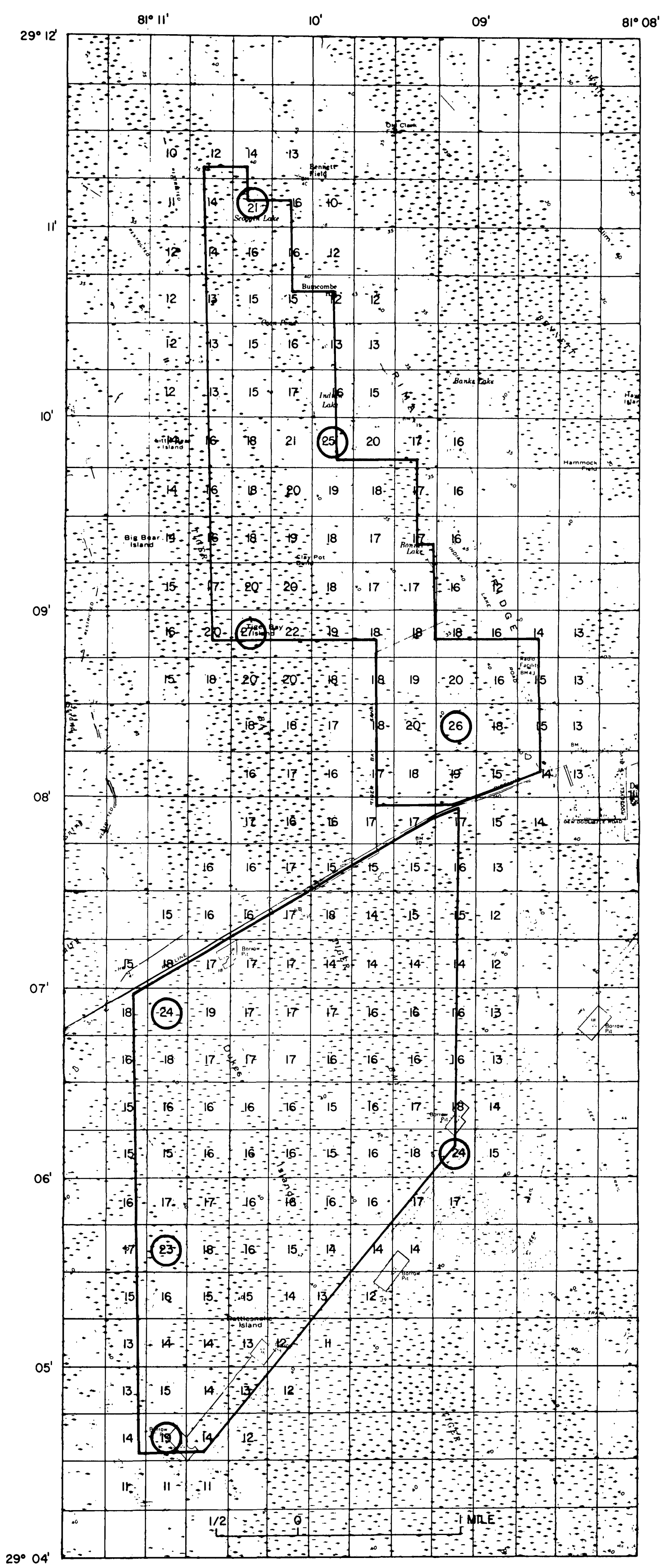

Figure 12.--Steady-state drawdown values for each node near the center of pumping due to withdrawal of 20 million gallons per day from 8 wells; leakage limited to a maximum of 14 inches per year. Circles indicate nodes containing wells. 



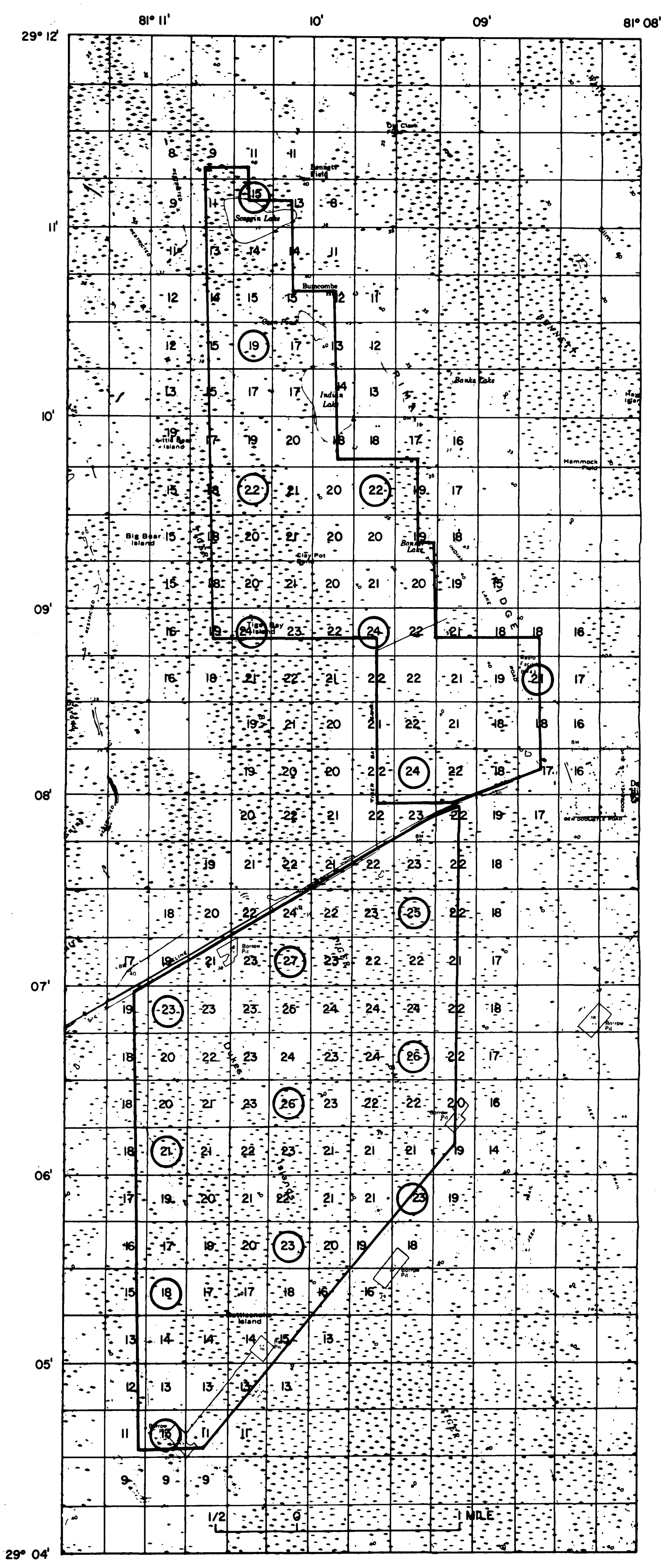

Figure 13.--Steady-state drawdown values for each node near the center of pumping due to withdrawal of 20 million gallons per day from 18 wells; leakage limited to a maximum of 14

inches per year. Circles indicate nodes containing wells. 

for well-field configurations consisting of 8 and 18 wells, respectively. For a pumpage of 20 million gallons per day, the maximum average drawdown in each configuration was about 3 feet more at the deepest part of each cone of depression than the maximum average drawdown with 67 wells (fig. 10).

To simulate the configuration of the cone of depression of an operating well field withdrawing 20 million gallons per day if water potentially available to recharge the Floridan aquifer were removed from the system, computer runs were made in which the maximum allowable recharge in the well-field area was reduced to 11 inches per year, and to 5 inches per year. Reducing the maximum potential leakage to 11 inches per year affected the cone of depression hardly at all. The depth of the cone increased only 0.6 foot at the center. This indicated that only a few nodes leaked more than 11 inches per year in model runs allowing more than 11 inches leakage per year.

Restricting leakage to 5 inches per year deepened the cone of depression markedly. At the center, drawdown was as much as 6.5 feet more than it would have been if as much as 14 inches of leakage per year was allowed. Figure 14 shows the cone of depression with leakage limited to 5 inches per year. Figure 15 shows the cone of depression superimposed on the unstressed potentiometric surface. Since less leakage per node occurred at some nodes with leakage restricted, the area of influence of the cone of depression had to increase to sustain a 20-million-gallon-per-day well field. The estimated area of influence shown in figure 14 was 180 square miles, resulting in an average induced leakage rate of 2.3 inches per year. 


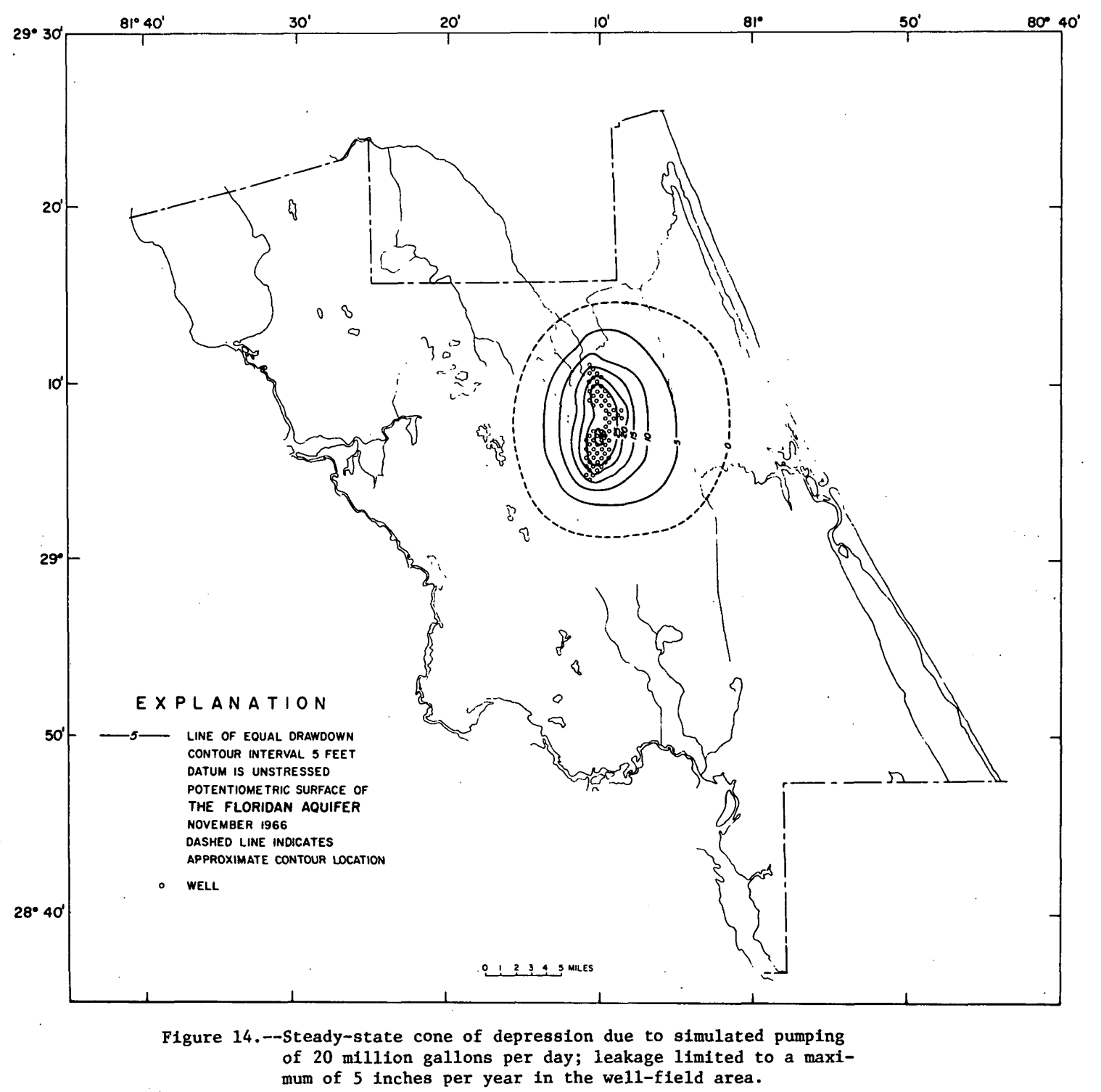




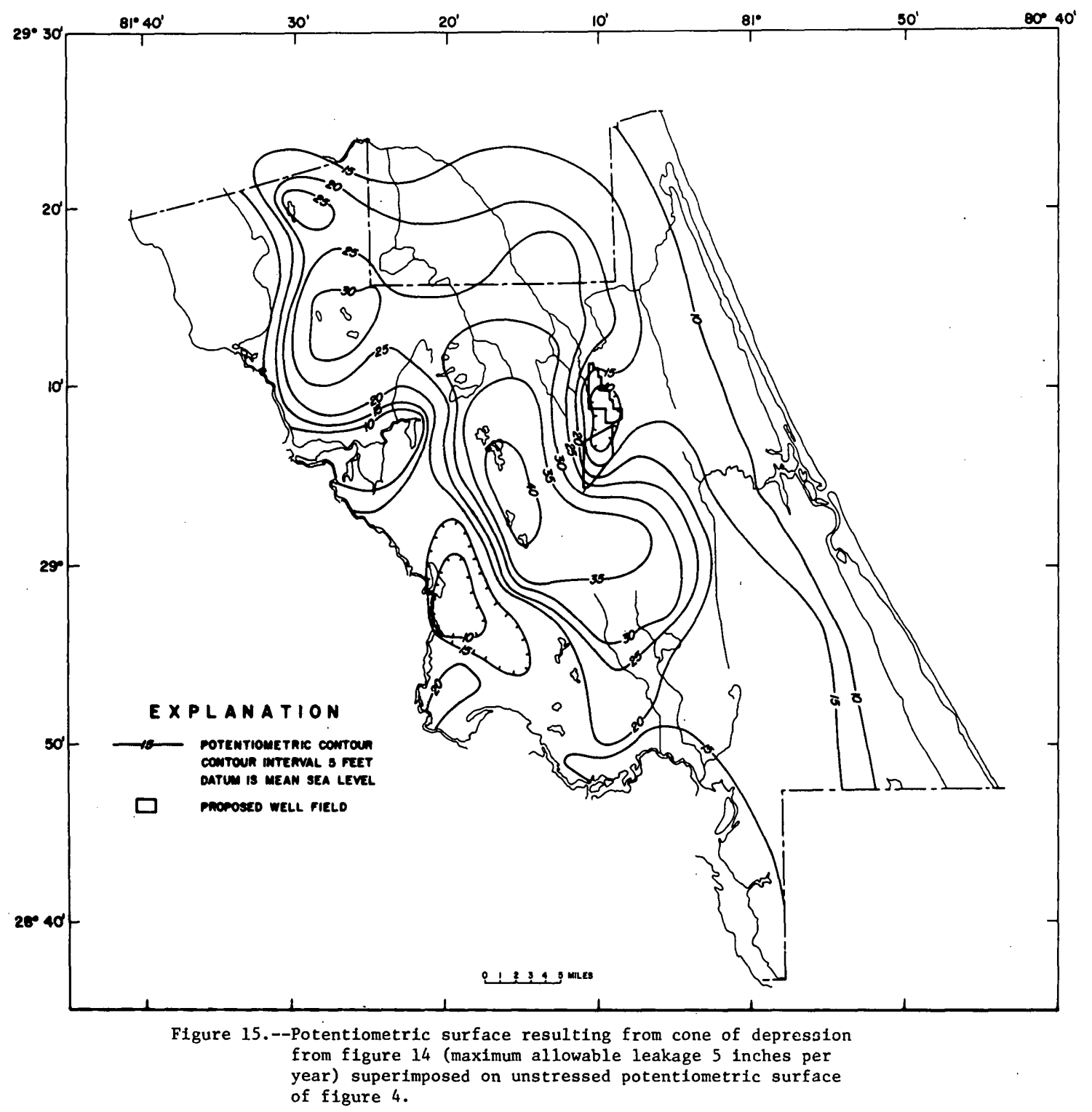


To simulate redistribution of potential recharge in the area of influence of the well field, computer runs were made first with leakage restricted to 5 inches per year in every other node in the well-field area, and leakage unrestricted in adjacent nodes. Second, leakage was restricted to 5 inches per year in every third node, and unrestricted leakage allowed in other nodes. The cones of depression for both runs were very similar. Restricting leakage to 5 inches per year in every other node caused drawdown 0.5 foot greater at the deepest point than restricting leakage in every third node, and drawdown 2 feet deeper than in the case where leakage was restricted to 14 inches per year in every node. Figure 16 shows the cone of depression resulting from a 20-million-gallon-per-day well field with leakage restricted to 5 inches per year in every other node, and unlimited leakage in other nodes. Figure 17 is this cone superimposed on the unstressed potentiometric surface of the Floridan aquifer.

\section{CONCLUSIONS}

1. About 20 million gallons per day is estimated to be the longterm average amount of water that can be withdrawn from the well-field property while being reasonably certain that no saltwater intrusion from the deep zones of the Floridan aquifer would occur. The controlling factors on the potential for saltwater intrusion into the pumped zone are the head in the aquifer at the freshwater-saltwater interface (and thus the gradient between the interface and the pumped zone) and the hydraulic conductivity of the layers of earth materials between the interface and the pumped zone. Because neither of these factors is very 


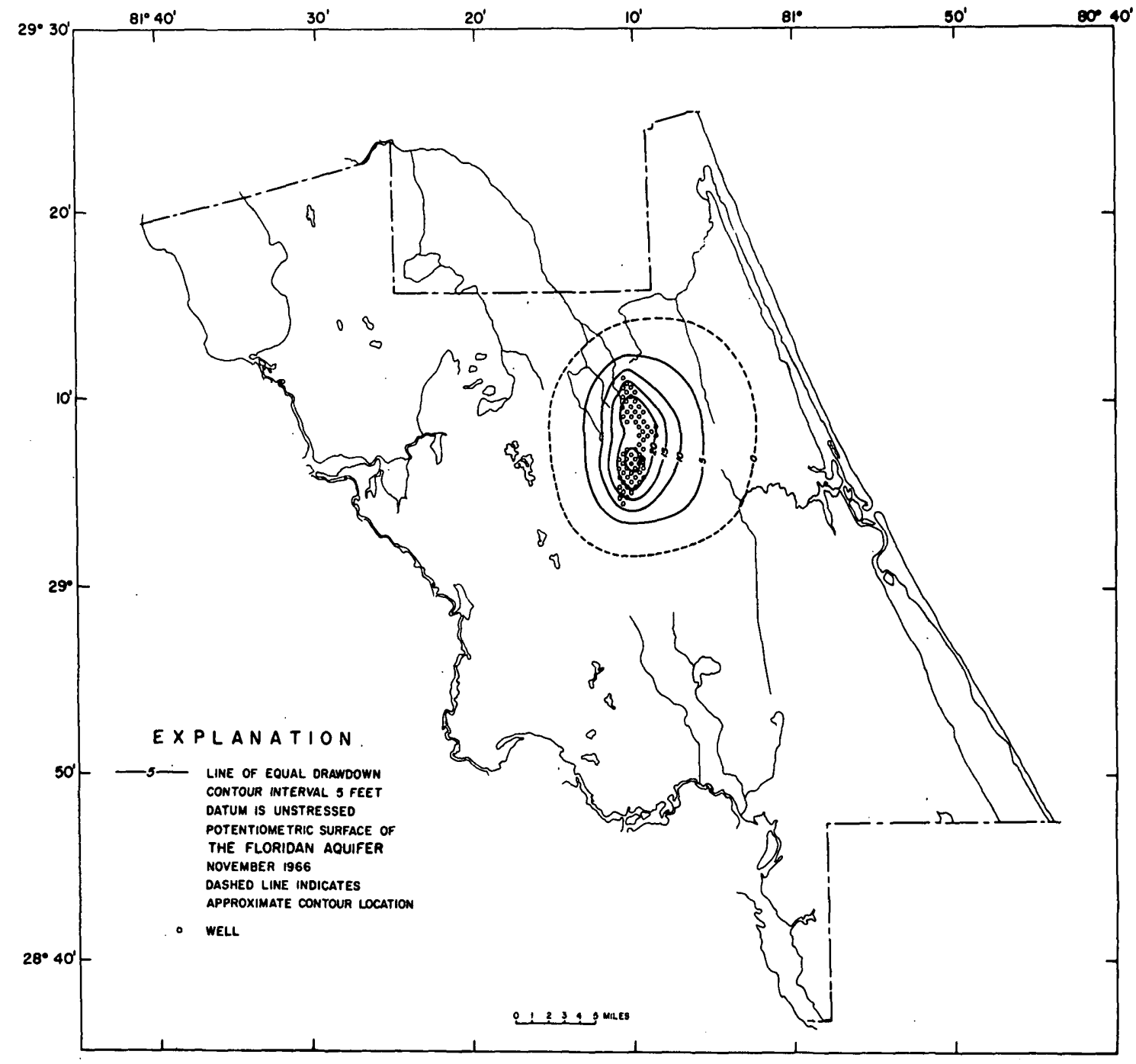

Figure 16.--Steady-stage cone of depression due to simulated pumping of 20 million gallons per day; leakage 1imited to 5 inches per year in every other node in the well-field area, leakage unrestricted in all other nodes. 


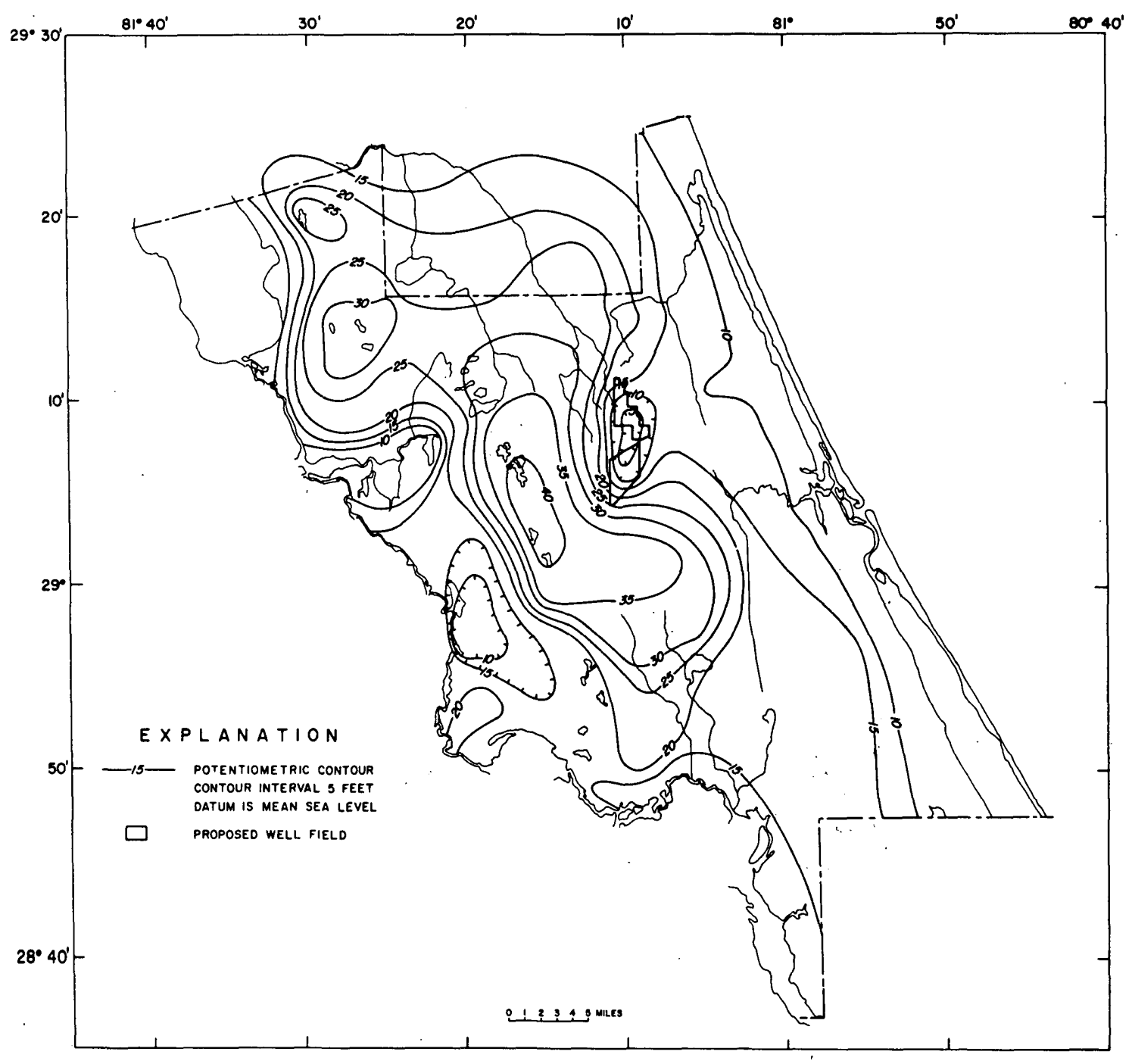

Figure 17.--Potentiometric surface resulting from cone of depression from figure 16 (20 million gallons per day, maximum allowable leakage 5 inches per year in every other node, unrestricted in all other nodes) superimposed on unstressed potentiometric surface of figure 4 . 
well known, a degree of risk will be involved with any appreciable withdrawal rate. Water-level (head) and water-quality (chloride) monitoring in the aquifer between the freshwater-saltwater interface and the pumped zone will be necessary as a well field is developed. Twenty million gallons per day is believed to be a conservative withdrawal rate. A considerably greater long-term average withdrawal rate may ultimately be possible without an appreciably greater risk of saltwater intrusion. However, only after some pumping experience with a developed well field is obtained, together with some data from a judiciously designed monitoring network, could an optimum long-term withdrawal rate be determined.

Implicit in the discussion of long-term yield above is the assumption that, when a central well field is developed and operational, pumping from the present Daytona Beach well field will cease. Model tests were made without simulating pumping from the Daytona Beach well field. To minimize the risk of lateral saltwater intrusion, it is important that a divide be maintained on the potentiometric surface between the coast and the cone of depression of the central well field.

2. Considerable latitude in well-field design would be possible for a given withdrawal rate, because the model analysis indicated only small differences in the altitude of the cone of depression for different well-field configurations. 
3. The tests with limited leakage from the shallow water-table aquifer indicate that a large amount of potential recharge water would have to be removed from the system to cause an appreciable lowering of the cone of depression from a 20-million-gallon-per-day well field. Lowering the recharge potential by 20 percent ( 14 inches per year to 11 inches per year) apparently would have little effect on the cone. With the recharge potential cut 60 percent, the maximum depth of the cone of depression would, according to the model, increase 27 percent ( 6.5 feet); and the area of influence of the cone would expand by 20 percent. Whether or not the predicted 6.5-foot maximum increase in average drawdown would affect upward migration of saltwater from deep zones in the Floridan aquifer cannot be judged with available data.

Land development that would redistribute potential recharge, rather than drain it away from the system, would have the least effect on an operating well field. Holding ponds or surface impoundments that would, in effect, make more than 14 inches per year of recharge available in some areas, would compensate for the removal of potential recharge in other areas.

4. More than enough water is potentially available as leakage from the overlying water-table aquifer to sustain a well field on the recently acquired property withdrawing on the order of 20 million gallons per day.

5. As the well field is developed, the model calibration could be improved and verified by comparing measured drawdowns due to actual pumping to computer-predicted drawdowns due to simulated pumping, and by adjusting the input parameters until the two cones of depression match. 
The model would then be a more precise tool with which to estimate the effects of future alternatives for well-field construction and operation, and for land use. 


\section{REFERENCES}

Bermes, B. J. and others, 1963, Geology and ground-water resources of Flagler, Putnam, and St. Johns Counties, Florida: Florida Geo1. Survey Rept. Inv. 32, 97 p.

Knochenmus, D. D., 1968, Surface drainage characteristics in Volusia County, Florida: Florida Dept. Nat. Resources, Bur. Geol. Map Series 30 .

Knochenmus, D. D., and Beard, M. E., 1971, Evaluation of the quantity and quality of the water resources of Volusia County, Florida: Florida Dept. Nat. Resources, Bur. Geol. Rept. Inv. 57, 59 p. Pinder, G. F., 1970, A digital model for aquifer evaluation: U.S. Geol. Survey Techniques Water-Resources Inv., book 7, chap. C1, 18 p. Pride, R. W. and others, 1966, Hydrology of the Green Swamp area in central Florida: Florida Geol. Survey Rept. Inv. 42, 137 p.

Trescott, P. C., 1973, Iterative digital model for aquifer evaluation: U.S. Geol. Survey open-file rept., 63 p.

U.S. Army, Corps of Engineers, 1933, Geology and ground water (app. E), Waterway from Cumberland Sound, Georgia and Florida, to the Mississippi River: Jacksonville, Florida, Special Board Rept., $65 \mathrm{p}$.

Volusia Council of Governments, 1974, Water management, phase 2, Volusia County, Florida, 46 p.

Wyrick, G. G., 1960, The ground-water resources of Volusia County, Florida: Florida Geol. Survey Rept. Inv. 22, 65 p. 